\title{
Modelling the effects of land-use/land-cover changes on the near-surface atmosphere in southern South America
}

\author{
Adriana Beltrán-Przekurat, ${ }^{a *}$ Roger A. Pielke Sr, ${ }^{a}$ Joseph L. Eastman ${ }^{b}$ \\ and Michael B. Coughenour ${ }^{\mathrm{c}}$ \\ ${ }^{a}$ Department of Atmospheric and Oceanic Sciences and Cooperative Institute for Research in Environmental Sciences, University of Colorado, \\ Boulder, CO 80309, USA \\ b WindLogics Inc., 201 4th St NW, Grand Rapids, MN 55744, USA \\ c Natural Resource Ecology Laboratory, Colorado State University, Fort Collins, CO 80523, USA
}

\begin{abstract}
A fully coupled atmospheric-biospheric regional climate model, GEMRAMS, was used to evaluate potential effects of land-use/land-cover changes (LULCC) on near-surface atmosphere over a southern South American domain at seasonal time scales. In GEMRAMS, leaf area index and canopy conductance are computed based on modelled temperature, solar radiation, and the water status of the soil and air, allowing a two-way interaction between canopy and atmosphere. Several austral spring-early summer simulations were conducted using land cover representing current (i.e. agricultural landscape), natural (i.e. before European settlement), and afforestation scenarios for three periods associated with El NiñoSouthern Oscillation (ENSO) conditions. The shift to agriculture resulted in a generalized deerease in albedo, reducing the available energy at the near-surface. The energy partitioning between latent and sensible heat fluxes changed, leading to distinct temperature responses. A shift from grass to agriculture led to cooler and wetter near-surface atmospheric conditions. Warmer temperatures resulted from the conversion of wooded grasslands or forest to agriculture. The LULCC-induced signal was spatially heterogeneous and with a seasonal component associated with vegetation phenology. A significant decrease in maximum temperatures in the southern and central Pampas led to a decrease in the diurnal temperature range. Basing on some observational studies in this region our results suggest a potential strong influence of LULCC on the maximum temperatures in central Argentina in summer. Afforestation resulted overall in cooler temperatures. For both LULCC scenarios the direction of the energy fluxes and temperature changes remained in general the same in two extreme ENSO years, although for some vegetation conversions the signal reversed direction. Overall, the impacts were enhanced during a dry year, but the response also depended on the vegetation types involved in the conversion. The effects on precipitation were insignificant in the agriculture-conversion scenario and a general increase was found in the afforested scenario. Copyright (C) 2011 Royal Meteorological Society
\end{abstract}

KEY WORDS land-use land-cover change; regional climate modeling; southern South America; near-surface temperature; energy fluxes

Received 28 April 2010; Revised 23 March 2011; Accepted 26 March 2011

\section{Introduction}

Cultivation, afforestation-reforestation (A\&R), deforestation, and increases in irrigation areas are some landuse/land-cover changes (LULCC) that often lead to changes of surface and vegetation traits, like albedo, leaf area, roughness length, and root biomass, with the corresponding changes in near-surface temperature (e.g. Baidya Roy et al., 2003; Lawrence and Chase, 2010), humidity (e.g. Douglas et al., 2006) and precipitation (Pielke et al., 2007). Modifications of the characteristics of vegetation and underlying surface (i.e. soil moisture availability) can affect the exchanges of heat, moisture, momentum, gases, and aerosols in the lower troposphere, and hence, have an impact on regional and

\footnotetext{
* Correspondence to: Adriana Beltrán-Przekurat, Department of Atmospheric and Oceanic Sciences- CIRES. UCB 311, University of Colorado, Boulder, CO 80309, USA.

E-mail: adriana@ciresmail.colorado.edu
}

possibly global climate (e.g. Pielke et al., 2002). The direction (i.e. cooling or warming), and the strength of the changes depend on different factors, such as geographical area (i.e. high, tropical, mid-latitudes), the characteristics of the vegetation involved in the replacement (i.e. trees, grasslands, crops), and extent of the affected area. Radiative, via albedo changes, and non-radiative forcing, via changes in latent heat fluxes, are the main processes engaged in determining the impacts of the agricultural expansion on near-surface weather and climate (e.g. Pielke et al., 2002; Betts et al., 2007; Davin and de Noblet-Ducoudré, 2010; Lawrence and Chase, 2010).

The LULCC, although they occur worldwide, have intrinsically regional characteristics (Ramankutty and Foley, 1998). Their potential effects can be directly found on the regional weather and climate and therefore there is a need to regionally assess the impacts of anthropogenic changes on climate (NRC, 2005). This 
(a) Land-cover/land-use classification

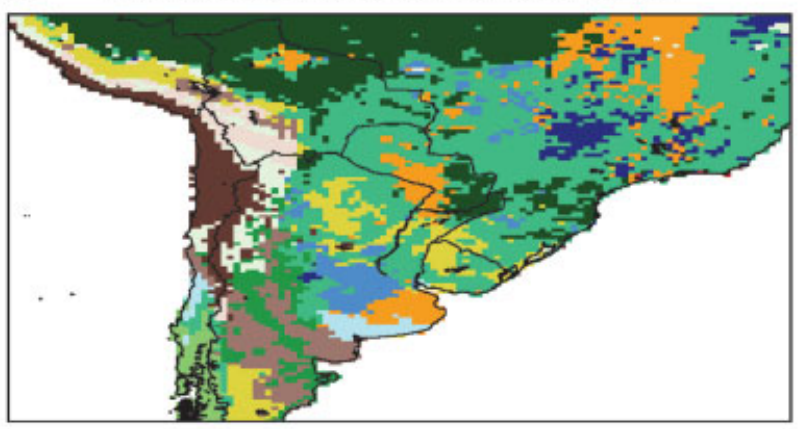

(b) Natural vegetation experiment NAT

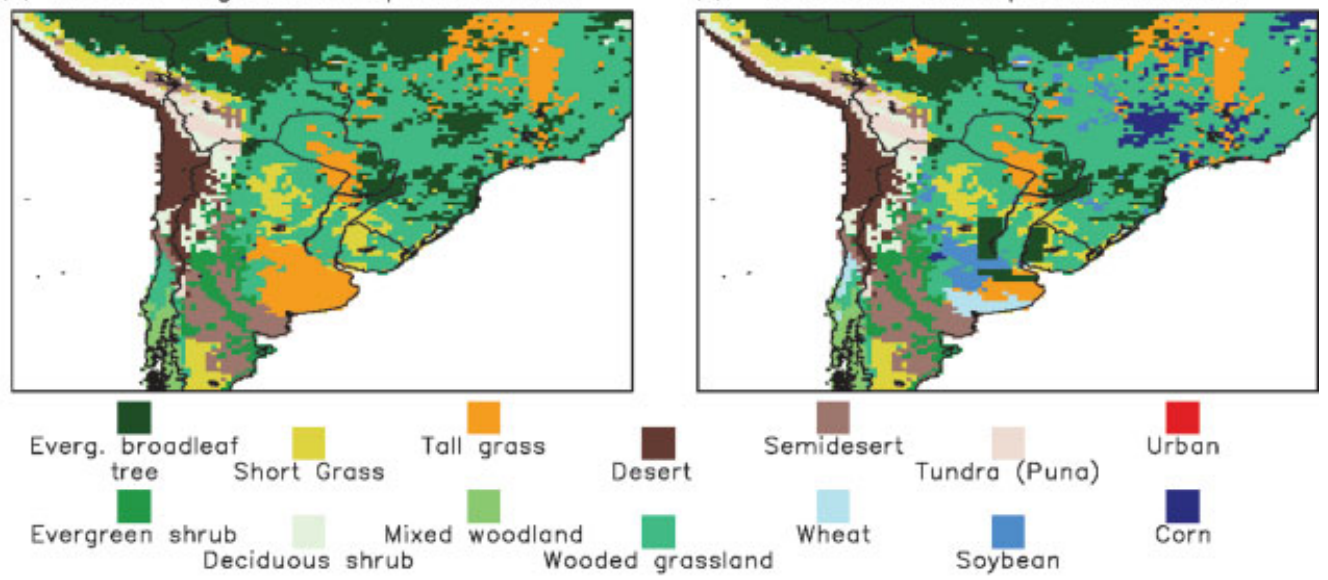

(d) CTRL-NAT Vegetation changes

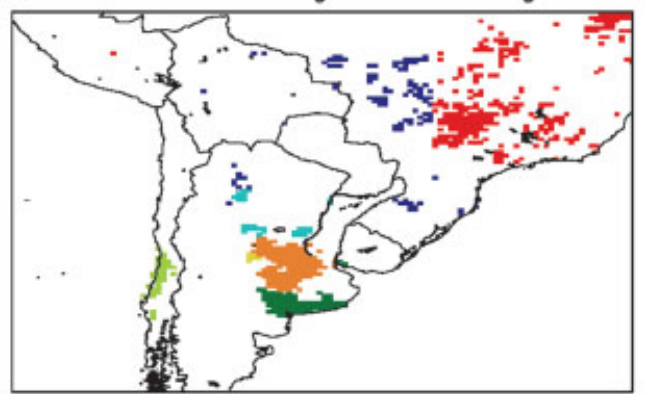

(e) AFFOR-CTRL Vegetation changes
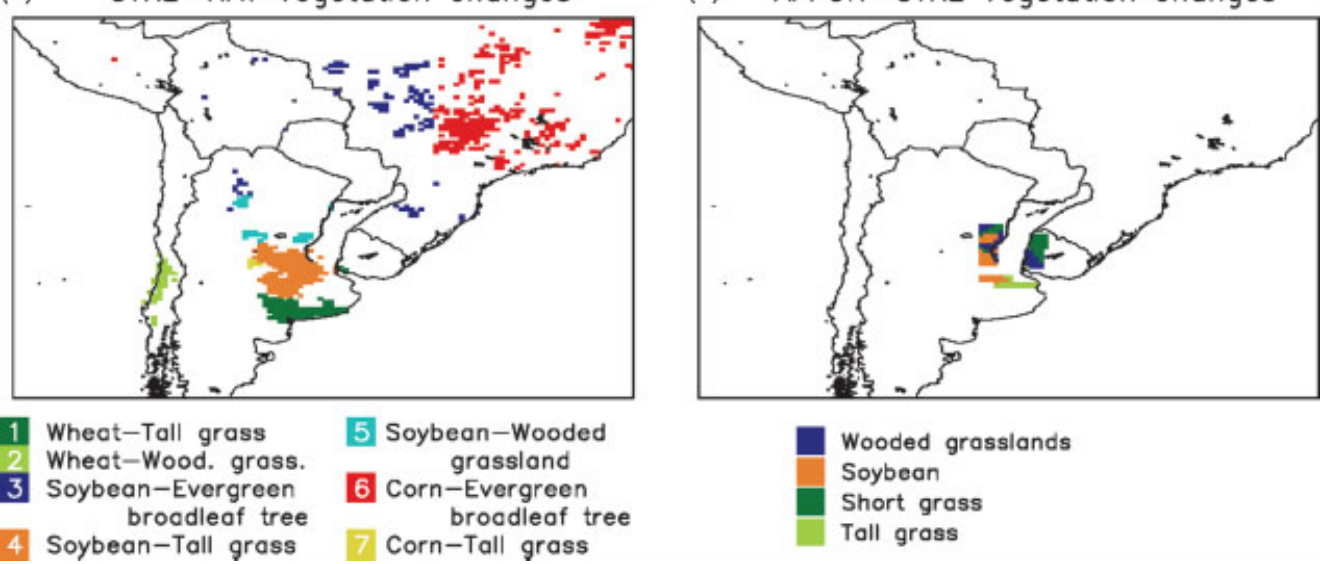

Wooded grasslands

Soybean

Short grass

Tall grass

Figure 1. Land-cover/land-use maps for each of the simulation experiments. a) Current vegetation used in the CTRL experiments. b) Land cover used in the Natural vegetation (NAT) experiment. c) Land cover used in the Afforestation (AFFOR) experiment. d) Changes in vegetation between Current and Natural experiments. The vegetation types in the legend are Current - Natural. e) Changes in vegetation between Afforestation and Current experiments. The vegetation types in the legend are the ones in the Current vegetation map, which were converted to Evergreen broadleaf tree in the AFFOR experiment. This figure is available in colour online at wileyonlinelibrary.com/journal/joc

work differs from other studies by focusing on the southern part of South America, i.e. south of $20^{\circ} \mathrm{S}$, in particular the southeastern region (Figure 1) where important LULCC similar to those in other regions of the world have occurred. Although several modelling studies have investigated the potential consequences of LULCC in other regions of the world, to our knowledge there has been no attempt to explore the potential impacts of LULCC on the near-surface atmosphere in the temperate South America region. Urbanisation and conversion of natural areas to agriculture/animal husbandry are two of the main LULCC in the past 100 years in this region. The area in Argentina dedicated to cropland increased from $610^{4} \mathrm{~km}^{2}$ in the $1910 \mathrm{~s}$ to $33.510^{4} \mathrm{~km}^{2}$ in 2000 (FAO, 2004). LULCC associated with agriculture has had an important effect on the structure and functioning of temperate ecosystems in the central-eastern part of Argentina, a region known as the Pampas (Guerschman and Paruelo, 2005; Vega et al., 2009). This area constitutes the main agricultural region of Argentina and one of the major agricultural regions in the world (Hall et al., 1992; Satorre, 2005). Not only 
has the land allocated to crops increased in this region but also the proportion of the three main annual crops in this area, wheat, corn, and soybean, has changed during the last century, with different trends within the Pampas (Viglizzo et al., 2006). On one hand, soybean showed a rapid increase from the late 1960s when they represented less than $2 \%$ of the total cultivated area, to represent $38 \%$ around 2004 (Paruelo et al., 2005). The expansion mostly occurred in the western and northwestern areas of the Pampas, and NE and NW of Argentina (Grau et al., 2005; Boletta et al., 2006). On the other hand, the main area cultivated with wheat, the southern part of the Pampas, has remained practically unchanged (Viglizzo et al., 1997).

In temperate South America (Argentina, Chile, Uruguay), as well as in subtropical southern South America (Bolivia, south of Brazil, Paraguay), natural forests have been drastically reduced since the beginning of the 20th Century (FAO, 2001). Most of the modelling studies addressing the impacts of LULC changes in South America are centred on tropical regions, particularly deforestation on the Amazon basin and desertification in northeast Brazil (e.g. Nobre et al., 1991; Hahmann and Dickinson, 1997; Baidya Roy and Avissar, 2002; Correia et al., 2007; Costa et al., 2007). Nevertheless, over the last two decades, A\&R plans supported through government economic incentives or subsidies have been implemented in Chile, Uruguay, and Argentina (World Bank, 2000). Since the implementation of the Clean Development Mechanism of the Kyoto Protocol in 2006, A\&R project activities in this region are being promoted as a way to offset carbon dioxide $\left(\mathrm{CO}_{2}\right)$ emissions through carbon sequestration projects (UNFCCC, 2008).

Regional atmospheric models represent an important tool to study the impacts of LULCC on nearsurface atmosphere at regional or continental scales. Leaf area index (LAI) is one of the vegetation characteristics used in atmospheric models that gives information about the amount of vegetation present. LAI constitutes a very interactive part of the climate system, playing a major role in influencing the surface fluxes. Satellite-derived data (i.e. Normalized Difference Vegetation Index, NDVI) can be used to estimate LAI (Sellers et al., 1996; Buermann et al., 2002). When using regional climate models (RCM) to perform dynamical downscaling from a larger-scale dataset or to address sensitivity to some internal or external forcing, it is possible to directly assimilate this LAI data as an 'observed' boundary condition for a given time. Nevertheless, there is no two-way interaction between vegetation and atmosphere in those simulations. However, when RCMs are used to assess potential effects of changes in vegetation the prognosis of LAI needs to be explicitly addressed within the modelling system. Most of the regional modelling studies of the LULCC impacts have used a fixed predetermined LAI (e.g. Marshall et al., 2004; Strack et al., 2008). In fully coupled atmosphere-biospheric regional models, LAI is computed based on modelled temperature, solar radiation, and the water status of the soil and atmosphere (Tsvetsinskaya et al. 2001a, 2001b; Eastman et al., 2001; Lu et al., 2001; Narisma et al., 2003; Beltrán, 2005). In this modelling-based study, we used GEMRAMS, the fully coupled atmospheric-plant model version of the Regional Atmospheric and Modeling System (RAMS). LAI, and canopy conductance are the two variables connecting the carbon and energy fluxes components of GEMRAMS' soil-vegetation-atmosphere transfer scheme.

In the cropland expansion, one of the main LULCC in this study area and in the world, structural and physiological crop changes like leaf area, root distribution, and stomatal conductance, are occurring throughout the growing season. Most of the modelling studies addressing LULCC impacts usually cover one or a few months or even less (e.g. Adegoke et al., 2003; Baidya Roy et al., 2003; Marshall et al., 2004; Georgescu et al., 2009). Our simulations extend from September to January (early spring to midsummer), covering approximately, the middle to the end of the wheat growing season, and the beginning to the middle of the corn and soybean growing period.

Interannual variability of the large-scale atmospheric conditions, for example, precipitation, can greatly affect the impacts of the LULCC on near-surface weather and climate. Variability in rainfall in the study region has been associated with the extreme phases of the El NiñoSouthern Oscillation (ENSO) phenomenon (Ropelewski and Halpert, 1987; Aceituno, 1988; Grimm et al., 2000; Penalba et al., 2005). Agricultural production in the Pampas, still mostly rainfed, has also been associated to the ENSO phenomenon (Podestá et al., 1999).

The work presented here is an extension of a previous LULCC impact modelling study by Beltrán (2005) over a similar temperate southern South America simulation domain. The overall objective of this work is to explore the near-surface atmosphere sensitivity to LULCC at a seasonal timescale using a fully coupled regional climate model, GEMRAMS. The modelling simulations are carried out over the mid-latitude South America and the specific research questions to be addressed in this study are as follows: (1) What are the potential impacts of land-use/land-cover changes (i.e. non-irrigated agriculture and afforestation) on nearsurface atmosphere in this region? (2) What is the potential role of the interannual variability in precipitation associated with ENSO events in the LULCC-induced signal?

This paper is organized as follows. An overview of the modelling system, the model set-up, the experimental design, soil and vegetation datasets and evaluation of the control experiments are described in Section 2. In Section 3 , the simulated effects of LULCC on near-surface atmosphere are examined. A summary and conclusions are given in Section 4. 
Table I. Changes (CTRL-NAT) of roughness length $\left(z_{0}, \mathrm{~cm}\right)$, albedo $\left(\alpha\right.$, unitless), leaf area index (LAI, $\left.\mathrm{m}^{2} \mathrm{~m}^{-2}\right)$ and rooting depth $(z \mathrm{r}, \mathrm{m})$ averaged for each of the vegetation conversions (Figure 1) for spring and summer. Second column is the percentage of grid cells $(\%)$ of the vegetation conversion, with respect to the total number of grid cells that experienced a vegetation change. The vegetation conversion corresponds to the current and natural land-cover. The conversions $4 \mathrm{~N}$ and $4 \mathrm{~S}$ are the northern and southern grid cells of the conversion 4 .

\begin{tabular}{|c|c|c|c|c|c|c|c|c|c|c|}
\hline \multirow[t]{2}{*}{ Vegetation conversion } & \multirow[t]{2}{*}{$\%$} & & \multicolumn{4}{|c|}{ Spring } & \multicolumn{4}{|c|}{ Summer } \\
\hline & & & $z_{\mathrm{o}}$ & $\alpha$ & LAI & $z \mathrm{r}$ & $z_{0}$ & $\alpha$ & LAI & $z \mathrm{r}$ \\
\hline Wheat-tall grass (1) & 12 & & 0.03 & 0.057 & 2.8 & 0.2 & -0.03 & 0.018 & 1.0 & 0.5 \\
\hline Wheat-wooded grasslands (2) & 5 & & -0.40 & 0.018 & 0.9 & -0.8 & -0.43 & -0.001 & -2.6 & -0.5 \\
\hline Soybean-evergreen broadleaf tree (3) & 15 & & -1.95 & 0.018 & -2.5 & -1.2 & -1.80 & 0.049 & -2.1 & -0.2 \\
\hline \multirow[t]{2}{*}{ Soybean-tall grass (4) } & 20 & $4 \mathrm{~N}$ & -0.02 & 0.012 & -0.7 & -0.2 & 0.03 & 0.035 & -0.8 & 0.8 \\
\hline & & $4 \mathrm{~S}$ & & 0.029 & 0.8 & -0.2 & & 0.052 & 2.2 & 0.7 \\
\hline Soybean-wooded grasslands (5) & 5 & & -0.45 & 0.001 & -1.9 & -1.2 & -0.35 & 0.016 & -1.6 & -0.2 \\
\hline Corn-evergreen broadleaf tree $(6)$ & 42 & & -1.95 & 0.022 & -0.8 & -1.2 & -1.80 & 0.045 & 0.0 & -0.5 \\
\hline Corn-tall grass (7) & 1 & & -0.02 & 0.026 & -1.0 & -0.2 & 0.03 & 0.040 & 0.2 & 0.9 \\
\hline
\end{tabular}

\section{The coupled modelling system and experiments}

\subsection{Overview of the models}

GEMRAMS, comprised of the Colorado State University 4.3 version of RAMS (Eastman et al., 2001; Cotton et al., 2003; Beltrán, 2005) and the General Energy and Mass Transport Model (GEMTM; Chen and Coughenour, 1994, 2004) was used in the simulations. GEMRAMS has been used to study the effects of land cover and $\mathrm{CO}_{2}$ changes on weather and climate in North America (Eastman et al., 2001), Australia (Narisma et al., 2003; Pitman et al., 2004), and South America (Beltrán, 2005). RAMS has been used to study precipitation over southeastern South America associated with strong lowlevel jet conditions (Nicolini et al., 2002); Weaver et al. (2002) studied the sensitivity of mesoscale circulations to model configuration in a domain centred over northwestern Brazil.

\subsection{Model configuration and experimental design}

The model was integrated over a domain covering the southern part of South America, approximately 8-45 $\mathrm{S}$ and $35-90^{\circ} \mathrm{W}$. The $124 \times 120$ grid had a $35-\mathrm{km}$-grid cell spacing and 32 vertical levels with a thickness of $60 \mathrm{~m}$ at the surface, stretching to $1 \mathrm{~km}$ from approximately $5.2 \mathrm{~km}$ to the domain top at $23 \mathrm{~km}$. The soil model had 8 soil layers, with the bottom layer at $3.0 \mathrm{~m}$.

The experiments covered a 5-month period, from September to January (early spring to mid-summer). Atmospheric lateral boundary conditions and initial atmospheric fields were provided by the European Centre for Medium-Range Weather Forecasts 40 year reanalysis (ERA-40). A 24-h timescale was applied for internal nudging. Climatological sea surface temperature from NCEP global one-degree grid data base were used on a daily basis update (Reynolds and Smith, 1994).

To isolate the effects of the land-cover changes, simulations were performed using the same atmospheric boundary conditions, namely the ERA-40 dataset for the period September-January of 1996-1997, 1997-1998, and 1999-2000. Those periods were chosen based on their ENSO classification. The period September 1996-January 1997 is classified as a non-ENSO event. The 1999-2000 La Niña event, was characterized by drought conditions from September 1999 to February 2000 in northeastern Argentina resulting in crop damage and production losses in most of the region (Ravelo and Zanvettor, 2000). The 1997-1998 period is considered one of the most important El Niño events (Camilloni and Barros, 2000).

For each of the 5-month periods, one control (CTRL) and two sensitivity simulations were performed. The CTRL experiments consisted of the GEMRAMS simulation that used the current vegetation description (Figure 1a), in next Section). The first sensitivity experiment, NAT, represents the conditions before European settlement. Croplands were replaced by tall grass, wooded grasslands, or evergreen broadleaf forest, depending on their geographical location (Figure 1b) and d) and Table I) (Beltrán, 2005). The second LULCC experiment, AFFOR, corresponds to an attempt to simulate a potential future afforestation scenario. Several grid cells were replaced by evergreen broadleaf trees based on the areas studied by Nosetto et al. (2005) and SAGYPA (2000) (Figure 1c) and e), and Table IV). Current vegetation cover (i.e. as in CTRL) was assumed in the rest of the model domain.

Results are presented as the difference of the averages for all periods between the CTRL simulation and each of the LULCC experiments (NAT and AFFOR) grouped in austral spring (October-November) and summer (December-January) seasons. The differences between the two extreme ENSO years, 1997-1998 minus 1999-2000 are also shown. Statistical significance of the daily averaged differences of near-surface latent $(\mathrm{LH})$ and sensible $(\mathrm{SH})$ fluxes, temperature, water vapour mixing ratio and precipitation between CTRL and NAT, and AFFOR and CTRL experiments was assessed with a $t$-test for each grid point, accounting also for autocorrelation (Zwiers and von Storch, 1995). 
Table II. Changes (CTRL-NAT) of sensible (SH) and latent heat $(\mathrm{LH})$ fluxes $\left(\mathrm{W} \mathrm{m}^{-2}\right)$, and Bowen ratio $(\beta=\mathrm{SH} / \mathrm{LH})$ averaged for each of the vegetation conversions (see Figure 1) for spring and summer. The vegetation conversion corresponds to the current and natural land-cover. The conversions $4 \mathrm{~N}$ and $4 \mathrm{~S}$ are the northern and southern grid cells of the conversion 4 . Statistical significant differences $(P<0.05)$ between CTRL and NAT experiments using the Student $t$-test are shown in bold.

\begin{tabular}{|c|c|c|c|c|c|c|c|}
\hline \multirow[t]{2}{*}{ Vegetation conversion } & & \multicolumn{3}{|c|}{ Spring } & \multicolumn{3}{|c|}{ Summer } \\
\hline & & SH & LH & $\beta$ & $\mathrm{SH}$ & LH & $\beta$ \\
\hline Wheat-tall grass (1) & & -43 & 38 & -47 & 2 & -21 & 14 \\
\hline Wheat-wooded grasslands (2) & & -2 & -12 & 10 & -22 & 1 & -10 \\
\hline Soybean-evergreen broadleaf tree (3) & & -23 & -1 & -19 & -21 & -10 & -15 \\
\hline \multirow[t]{2}{*}{ Soybean-tall grass $(4)$} & $4 \mathrm{~N}$ & 8 & -18 & 16 & -1 & -20 & 8 \\
\hline & $4 \mathrm{~S}$ & -40 & 35 & -45 & $-\mathbf{5 0}$ & 38 & -45 \\
\hline Soybean-wooded grasslands (5) & & -7 & -22 & 21 & -5 & -21 & 5 \\
\hline Corn-evergreen broadleaf tree (6) & & -5 & -11 & -2 & -2 & -20 & 4 \\
\hline Corn-tall grass $(7)$ & & 2 & -21 & 18 & -10 & -9 & -4 \\
\hline
\end{tabular}

\subsection{Soil and vegetation maps}

Horizontally heterogeneous soil texture information was derived from the $5 \times 5$ arc-minute Soil and Terrain (SOTER) database for Latin America and the Caribbean (SOTER, 1998). A uniform soil texture was assumed along the vertical profile which corresponded to the predominant soil texture class in the profile within each of the SOTER pixels.

In GEMRAMS, land cover can be represented by multiple patches within a grid cell (Walko et al., 2000); the land-cover classes are derived from a combination of the Biosphere-Atmosphere Transfer Scheme and the Land Data Assimilation System. In these simulations, only one land-cover type was considered which correspond to the dominant vegetation for each grid cell.

To take into account the distinct crop phenological cycle during the simulated 5-month period, the 'Crop/mixed farming' grid cells were reclassified into wheat, as the main winter crop, and soybean and corn, as the main summer crops, in most of the simulation domain, and as tall grass in a small central-eastern portion of the Pampas, an area mostly covered by cultivated pastures and native grasslands (Hall et al., 1992). County harvested area for 1996-2000 for each crop from the Agriculture Department of Argentina (SAGYPA, 2000), and maps from Ramankutty and Foley (1998) and USDA (1987) were the main sources used in the reclassification. Sowing and harvesting dates were derived from the NDVI temporal evolution based on the White et al. (1997) algorithm. The dates obtained were within the range of observed typical sowing and harvest dates for the region (USDA, 1987; Hall et al., 1992). Wheat is sowed around July (Hall et al., 1992) and harvested from midDecember to early January. In the case of summer crops, sowing occurs around early to mid-October and harvest occurs after the end of the simulation, around March for corn and April for soybean (Guerschman et al., 2003). Vegetation is assumed to shift to tall grass with a very low LAI after harvest, in the case of wheat grid cells, and before sowing for summer crops.
Irrigation was not accounted for in this modelling exercise because most of the agricultural production in the domain is still under rainfed conditions (Siebert et al., 2007). Figure 1a) shows the final land-cover distribution in the modelling domain. Vegetation types were also distinguished by $\mathrm{C}_{3}$ and $\mathrm{C}_{4}$ photosynthesis pathways based on Still et al. (2003) and Paruelo et al. (1998).

\subsection{Initialisation procedure}

Initial LAI and vegetation fraction were estimated using the $8 \mathrm{~km} \times 8 \mathrm{~km}$ bimonthly value of the Global Inventory Modeling and Mapping Studies Satellite Drift Corrected and NOAA-16 incorporated Normalized Difference Vegetation Index (GIMMS-NDVI) (Tucker et al., 2005) for September 1 of 1996, 1997, and 1999 using the algorithm proposed by Sellers et al. (1996). Details of the initial conditions for above- and below-ground biomass and root profiles setup can be found in Beltrán (2005) and Eastman et al. (2001).

Soil water content was initialized with the Soil Water Index (SWI; Wagner et al., 2003) derived from European Remote Sensing Satellites scatterometer. For all the simulations, the initial soil water conditions were computed combining the September SWI averaged for the period 1992-2000 and the values of wilting point, field capacity, and porosity associated with each soil texture (Wagner et al., 1999). Vertically uniform soil moisture content was assumed throughout the soil profile. Sensitivity to initial soil moisture conditions were performed for the 1996-1997 period for the CTRL and NAT experiments, using a spatially homogeneous percentage of saturation of $50 \%$ (shown in the Appendix).

\subsection{Model validation of the control experiments}

GEMRAMS was able to simulate well the observed spring and summer main circulation features, temperature, and precipitation over this South American domain for the three simulated periods, and also to characterize the observed precipitation and temperature differences between two ENSO years (Beltrán, 2005). GEMRAMS 


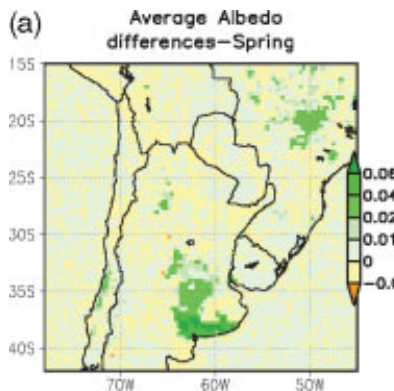

(b) Average Albedo
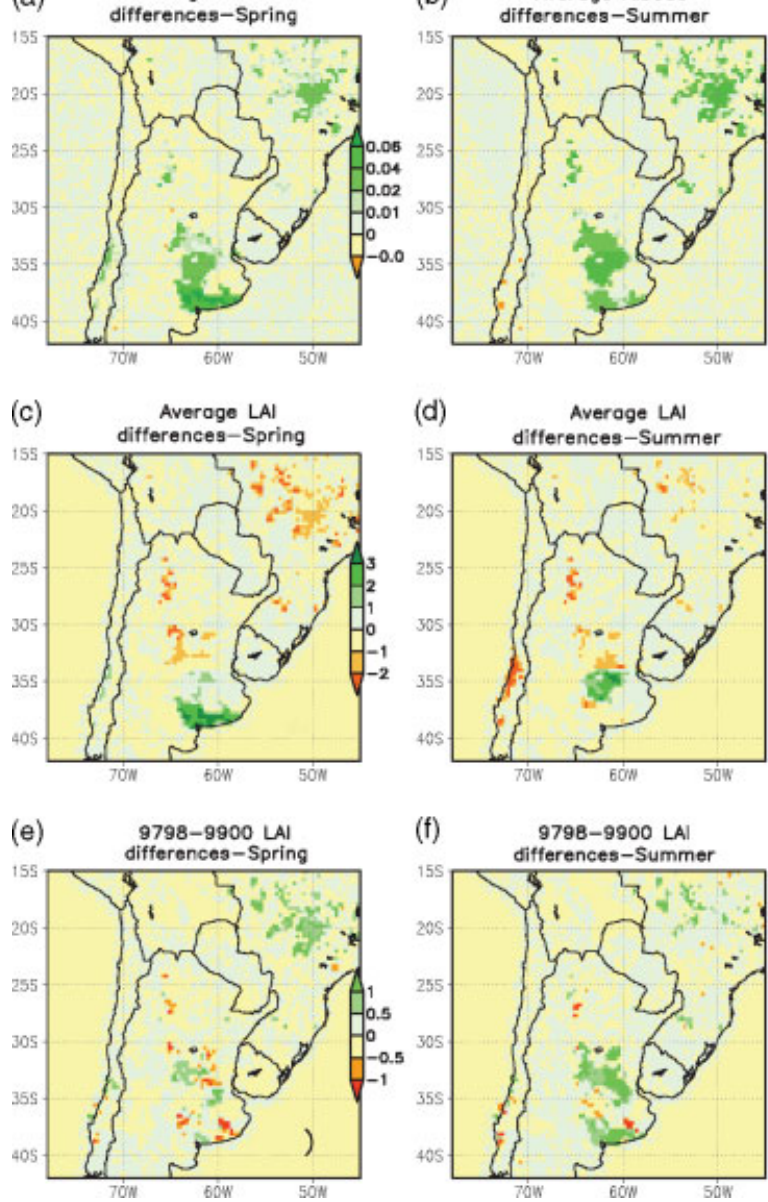
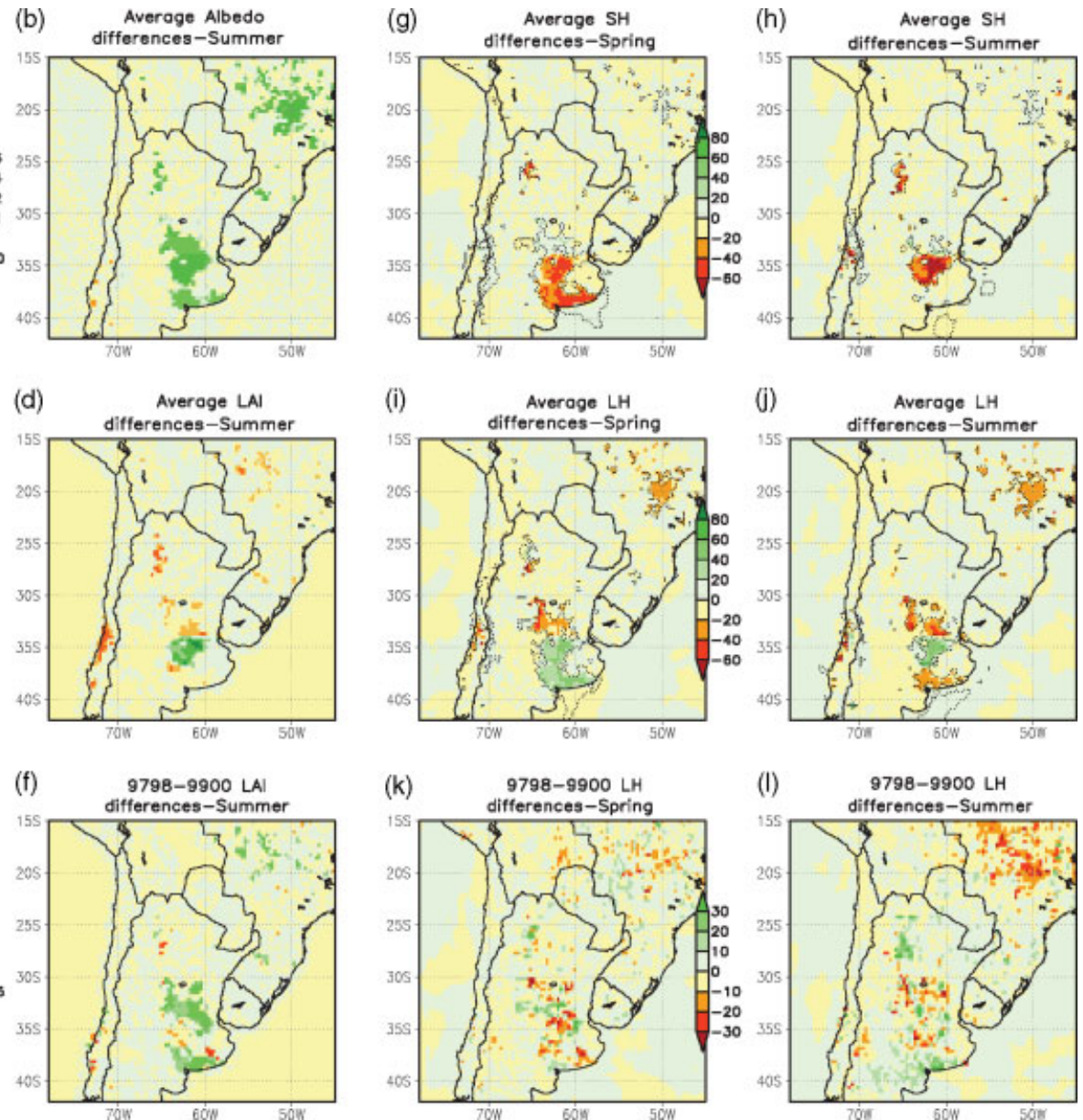

Figure 2. (a) Spatial changes CTRL - NAT of albedo (unitless) averaged for the three periods for spring; (b) Idem (a) for summer; (c) Spatial changes CTRL - NAT of LAI $\left(\mathrm{m}^{2} \mathrm{~m}^{-2}\right.$ ) averaged for the three periods for spring; (d) Idem (c) for summer. (e) Differences between $1997-1998$ and 1999-2000 of LAI CTRL - NAT changes for spring. (f) Idem (e) for summer. (g) Spatial changes CTRL - NAT of sensible heat (SH, $\mathrm{W} \mathrm{m}^{-2}$ ) averaged for the three periods for spring; (h) Idem (g) for summer. (i) Idem ( $\mathrm{g}$ ) for latent heat $\left(\mathrm{LH}, \mathrm{W} \mathrm{m}^{-2}\right.$ ); (j) Idem (i) for $\mathrm{LH}$ (W m ${ }^{-2}$ ); (k) Differences between 1997-1998 and 1999-2000 of LH CTRL - NAT changes for spring. (l) Idem (k) for summer. Contoured are the differences with statistical significance greater than $95 \%$. This figure is available in colour online at wileyonlinelibrary.com/journal/joc

also captured the physiological differences between vegetation types (Beltrán, 2005). A detailed analysis of GEMRAMS performance in this domain is given in Beltrán (2005), but we included in the Appendix the validation of the simulated precipitation for 1997-1998 and 1999-2000, years with El Niño and La Niña characteristics, respectively. We also include a sensitivity test of the LULCC impacts to initial soil moisture conditions.

\section{Results and discussion}

3.1. LULCC sensitivity experiments: current versus natural vegetation scenario

\subsubsection{Vegetation characteristics}

Two main areas with vegetation changes are identified in Figure 1d). The largest converted area is located in southern Brazil, where broadleaf trees were assumed to be replaced by corn in $42 \%$ of the modified grid cells and by soybean in $15 \%$ (Table I). The other area is located over the Pampas region, with a 20 and $12 \%$ of the changed grid cells converted from tall grass to soybean and wheat, respectively (Table I). These conversions have associated changes in vegetation characteristics, like albedo, LAI, roughness length (zo) and rooting depth (zr) (Table I and Figure 2).

Overall, albedo of current vegetation was higher than that of natural vegetation (Figure 2a), b)). Area-averaged albedo differences between the CTRL and NAT experiments were higher in summer than in spring, except for the grid cells with wheat. This is a consequence of the growing cycle of the crops. Wheat harvest occurs from mid-December to early January. As summer progresses, the number of grid cells in the CTRL experiment with similar albedo to the NAT experiment increases, and therefore, the averaged albedo differences for the wheat-tall grass conversion area decreases from 0.057 in spring to 0.018 in summer (Table I). Conversely, in the case of summer crops, which are sowed around early to mid-October, the number of grid cells in the CTRL experiment with different albedo than the natural vegetation increases through January leading to an increase in the area-averaged albedo differences between CTRL and NAT experiments from spring to summer (Table I). 
Different crop phenology is also reflected in LAI differences between CTRL and NAT experiments in spring and summer (Table I and Figure 2c) and d)). Conversion from natural vegetation to wheat increased LAI during spring and decreased LAI in summer due to the harvest starting around mid December. Within the grid cells that converted from tall grass to soybean (Table I), two areas of opposite behaviour were found (Figure 2d)) and Table I). In the northern part (4N in Table I), where grasslands were assumed to have a $\mathrm{C}_{4}$ photosynthetic pathway, LAI was slightly lower under current conditions than with natural vegetation (Figure 2d)). On the other hand, in the southern part, where grasslands were assumed to be $\mathrm{C}_{3}$ ( $4 \mathrm{~S}$ in Table I) LAI was higher in the CTRL than in NAT experiment. For both $4 \mathrm{~N}$ and $4 \mathrm{~S}$ areas the average LAI differences (in absolute values) were higher during summer as more grid cells shift to soybean. A shift from broadleaf tree or wooded grasslands to soybean and corn resulted in lower LAI values (conversions 3, 5, and 6 in Table I, respectively, and Figure 2c) and d)).

Overall, a shift from natural to current vegetation resulted in decreased zo and zr. The largest decreases were concentrated in Brazil, associated with the tree-tocrop conversion (conversions 3 and 6 in Table I), and followed by the wooded grasslands-to-crop conversion (conversions 2 and 5 in Table I). There was also a seasonal variation, related to the different crop phenology.

Interannual variability. We now look at how the changes in the vegetation characteristics with the shift to an agricultural scenario could be affected by different precipitation patterns in two ENSO years. Similar spatial patterns of albedo changes CTRL-NAT were found for the two extreme ENSO years and interannual differences of those changes were small (not shown). LAI differences CTRL-NAT between 1997-1998 and 1999-2000 are within the 3-years average differences range (compare Figure 2c) and d) with Figure 2e) and f)). The direction of the LAI CTRL-NAT changes remains the same for both periods, but in some areas the signal is enhanced during the overall 1999-2000 dry period (Figure A.1 in the Appendix). In the areas where the 3-years average LAI CTRL-NAT differences are negative, i.e. north and central part of the domain (Figure 2c)) and d)), those differences become more negative during 1999-2000, i.e. positive values in Figure 2e) and f). This indicates that LAI for the current vegetation decreases more than for the natural vegetation during dry conditions. In other areas, like in the southern Pampas, the signal is also enhanced during the same 1999-2000 period but under wet conditions: e.g. during summer in this area, precipitation is actually higher in 1999-2000 than in 1997-1998 (Figure A.1 in the Appendix). The higher precipitation increases the LAI of the natural vegetation (tall grass), and because wheat is being harvested during that time of the year, the LAI CTRL-NAT differences are larger in absolute value during the period 1999-2000 than during 1997-1998.

\subsubsection{LULCC effects on near-surface sensible and latent heat fluxes}

A replacement of natural vegetation by crops decreased $\mathrm{SH}$ in most of the simulation domain in both seasons (Figure $2 \mathrm{~g}$ ) and $\mathrm{h}$ ), and Table II). The largest statistically significant SH differences between the CTRL and NAT experiments were found in the southern portion of the grid cells that converted from tall grass and evergreen broadleaf tree to soybean throughout the simulation (areas 4S and 3, Table II), and in the ones converted to wheat in the southern Pampas during spring (conversion 1, Table I). Small areas with statistically significant positive SH differences were found in the centre and northeastern part of the domain throughout the simulation and non-significant in the southern Pampas during summer (Figure 2g) and h), Table II).

The changes in LH showed the opposite pattern of $\mathrm{SH}$ changes in grid cells that converted from wheat and soybean to grasses (Figure 2i) and j), Table II). LH values were higher over crops when shift was from $\mathrm{C}_{3}$ grasslands (conversion 1 and $4 \mathrm{~S}$, Table II). The increase in albedo decreases the available energy (SH plus LH), and in these converted areas the LAI increase led to higher $\mathrm{LH}$ and lower $\mathrm{SH}$ in the current vegetation, i.e. a shifting in the energy partitioning toward LH. In the rest of the LULCC areas, average LH was lower in the current vegetation (i.e. crops) than in natural vegetation (Table II). In most of these areas, SH also showed a decrease (when trees and wooded grasslands were involved, conversions $2,3,5$, or 6 ). The lower amount of available energy combined also with lower LAI and rooting depth in the current vegetation, lead to a decrease in LH and SH in the CTRL experiments. In other areas, SH slightly increased when conversion was from $\mathrm{C}_{4}$ grasses ( $4 \mathrm{~N}$ and 7 , Table II). Seasonal variation in the LH and SH CTRL-NAT differences appeared associated with the crops growing cycle, through the LAI and rooting depth seasonal evolution.

Bowen ratio $(\beta)$ values, the ratio between $\mathrm{SH}$ and $\mathrm{LH}$, indicates how the available energy is partitioned between $\mathrm{LH}$ and SH. Changes in $\beta$ for each of the vegetation conversion are shown as a percentage with respect to natural cover in Table I. The largest relative changes in $\beta$ were $47 \%$ and negative, indicating that more energy is now being used in transpiration and evaporation than in heating the near-surface atmosphere; therefore a net cooling effect is expected in that region. The largest positive change, of $26 \%$, was found in spring in the few grid cells that shifted from wooded grasslands to soybean (Table II). There was also a seasonal variation in $\beta$ changes, with values generally lower in summer than in spring.

Interannual variability. Latent heat differences CTRLNAT between 1997-1998 and 1999-2000 are shown in Figure 2k) and l) and in Table III. Similar to LAI, the changes are within the average LH differences, and tended to be higher and more spatially coherent during summer. In most of the simulation domain, the direction of the LH changes is the same for both periods 
Table III. Austral spring and summer changes (CTRL-NAT) of sensible (SH) and latent heat (LH) fluxes (W m ${ }^{-2}$ ), two-metre temperature $\left(2 \mathrm{mt},{ }^{\circ} \mathrm{C}\right.$ ) and precipitation (PR, mm), averaged for each of the vegetation conversions (see Figure 1) for the El Niño (1997-1998) and La Niña years (1999-2000). The vegetation conversion corresponds to the current and natural land-cover. The conversions $4 \mathrm{~N}$ and $4 \mathrm{~S}$ are the northern and southern grid cells of the conversion 4 . Statistical significant differences $(P<0.05)$ between CTRL and NAT experiments using the Student $t$-test are shown in bold.

\begin{tabular}{|c|c|c|c|c|c|c|c|c|c|c|c|c|c|c|c|c|c|}
\hline \multirow{3}{*}{$\begin{array}{l}\text { Vegetation } \\
\text { conversion }\end{array}$} & & \multicolumn{8}{|c|}{$1997-1998$} & \multicolumn{8}{|c|}{ 1999-2000 } \\
\hline & & \multicolumn{4}{|c|}{ Spring } & \multicolumn{4}{|c|}{ Summer } & \multicolumn{4}{|c|}{ Spring } & \multicolumn{4}{|c|}{ Summer } \\
\hline & & $\mathrm{SH}$ & LH & $2 \mathrm{mt}$ & PR & SH & LH & $2 \mathrm{mt}$ & PR & SH & LH & $2 \mathrm{mt}$ & PR & SH & LH & $2 \mathrm{mt}$ & PR \\
\hline $\begin{array}{l}\text { Wheat-tall grass } \\
\text { (1) }\end{array}$ & & -40 & 35 & -1.0 & -2 & -6 & -14 & -0.1 & -2 & $-\mathbf{5 0}$ & 45 & -1.1 & 1 & -5 & -5 & 0.0 & 10 \\
\hline $\begin{array}{l}\text { Wheat-wooded } \\
\text { grasslands (2) }\end{array}$ & & 7 & -28 & 0.5 & -1 & 19 & -50 & 1.2 & 0 & 12 & -1 & 0.3 & -3 & -21 & 28 & 0.2 & 1 \\
\hline $\begin{array}{l}\text { Soybean-evergreen } \\
\text { broadleaf tree (3) }\end{array}$ & & -3 & -2 & 0.5 & -2 & -5 & -8 & 0.5 & -6 & -4 & 10 & 0.6 & 9 & -4 & -10 & 0.6 & 2 \\
\hline $\begin{array}{l}\text { Soybean-tall grass } \\
\text { (4) }\end{array}$ & $4 \mathrm{~N}$ & 3 & -18 & -0.1 & 0 & 0 & -26 & -0.2 & -3 & 12 & -15 & 0.1 & 4 & 9 & -16 & 0.1 & 12 \\
\hline & $4 \mathrm{~S}$ & -41 & 35 & -0.8 & -1 & -57 & 37 & -1.0 & -8 & -41 & 41 & -0.7 & 2 & -63 & 67 & -1.0 & 10 \\
\hline $\begin{array}{l}\text { Soybean-wooded } \\
\text { grasslands (5) }\end{array}$ & & 7 & -45 & 0.8 & -4 & -25 & -18 & 0.2 & -15 & 24 & -33 & 0.8 & 4 & 6 & -32 & 0.4 & 10 \\
\hline $\begin{array}{l}\text { Corn-evergreen } \\
\text { broadleaf tree }(6)\end{array}$ & & -1 & -15 & 0.7 & 2 & -6 & -32 & 0.6 & -4 & 10 & -25 & 0.6 & 19 & 5 & -22 & 0.5 & 11 \\
\hline Corn-tall grass (7) & & -3 & -15 & 0.0 & -1 & -18 & -6 & -0.3 & -6 & 4 & -19 & 0.3 & 1 & -8 & 3 & -0.1 & 8 \\
\hline
\end{tabular}

and seasons, but the response to wet or dry conditions varies depending on the LULCC. For example, in Brazil around $20^{\circ} \mathrm{S}, 50^{\circ} \mathrm{W}$, during wet conditions in summer 1997-1998, LH for trees increased more than corn, leading to an area-average CTRL-NAT difference of $-32 \mathrm{~W} \mathrm{~m}^{-2}$ versus $-22 \mathrm{~W} \mathrm{~m}^{-2}$ during 1999-2000 (conversion 6, Table III). This can be due to a combination of factors: deeper rooting depth, larger canopy conductance, and higher roughness length in the natural vegetation compared to crops. Also in summer, in the southern Pampas (conversion 1, Table III), LH changes were larger in 1999-2000 during slightly wetter conditions than in the drier 1997-1998 conditions (Figure A.1 in the Appendix). Wheat is being harvested during summer; therefore the wetter conditions affect more the natural vegetation. On the other hand, in the central part of the domain, during the summer dry period 1999-2000 area-average LH for both current and natural vegetation decrease, but $\mathrm{LH}$ for soybean decreased more than for grasslands (conversion 5, Table III). This leads to larger LH absolute differences CTRL-NAT during 1999-2000 $\left(-32 \mathrm{Wm}^{-2}\right)$ than in 1997-1998 $\left(-18 \mathrm{Wm}^{-2}\right)$ (Table III). Slightly low canopy conductance in soybean and deeper rooting depth for wooded grasslands were the main factors that could explain this pattern.

\subsubsection{LULCC effects on near-surface temperature and humidity}

Changes in near-surface fluxes led to changes in nearsurface temperature and water vapor (Figure 3 and Table III). With a current land cover, a cooler nearsurface atmosphere was found associated with higher LH and lower SH fluxes, and vice versa, warming was associated with lower LH and SH fluxes. Near-surface temperatures decreased when crops (wheat and soybean) replaced $\mathrm{C}_{3}$ grasslands, as in the southern Pampas (Figure 3a), b) and Table III). Increases in temperature were found when vegetation shifted from evergreen trees, wooded grasslands (e.g. in Brazil), and $\mathrm{C}_{4}$ grasslands (e.g. in the central region of the Pampas) to crops (Figure 3a), b)). This is the result of the simulated higher LAI and therefore $\mathrm{LH}$ in $\mathrm{C}_{4}$ grasslands than in $\mathrm{C}_{3}$ grasslands and crops due to a higher dry matter growth rate related to their different photosynthetic rates (Chen and Coughenour, 1994; Larcher, 1995). The coolest (up to $-0.8^{\circ} \mathrm{C}$ ) and warmest (higher than $0.6^{\circ} \mathrm{C}$ ) two-metre average temperature differences appeared during spring in the southern and northern part of the domain, respectively. Temperature differences between current and natural cover became smaller at the first model level (approximately at $57 \mathrm{~m}$ ) but changes were statistically significant up to $1000 \mathrm{~m}$ (not shown).

The warming or cooling was consistent for both seasons for most of the areas with the LULCC, except for the southern Pampas. In this region, a net cooling was found in spring while a small net warming was present in summer. As mentioned before, this is a consequence of the phenology of the crop in this area, wheat. This is the harvesting period, and vegetation was assumed tall grass after harvest, same as the natural vegetation, but with a lower LAI and vegetation cover; therefore LH was higher in NAT than in CTRL experiments during summer in this area. A similar response was found in the observed temperature and humidity for the Oklahoma's winter wheat belt in the US (McPherson et al., 2004). They found that during the wheat growing season maximum temperatures were statistically significantly cooler and 

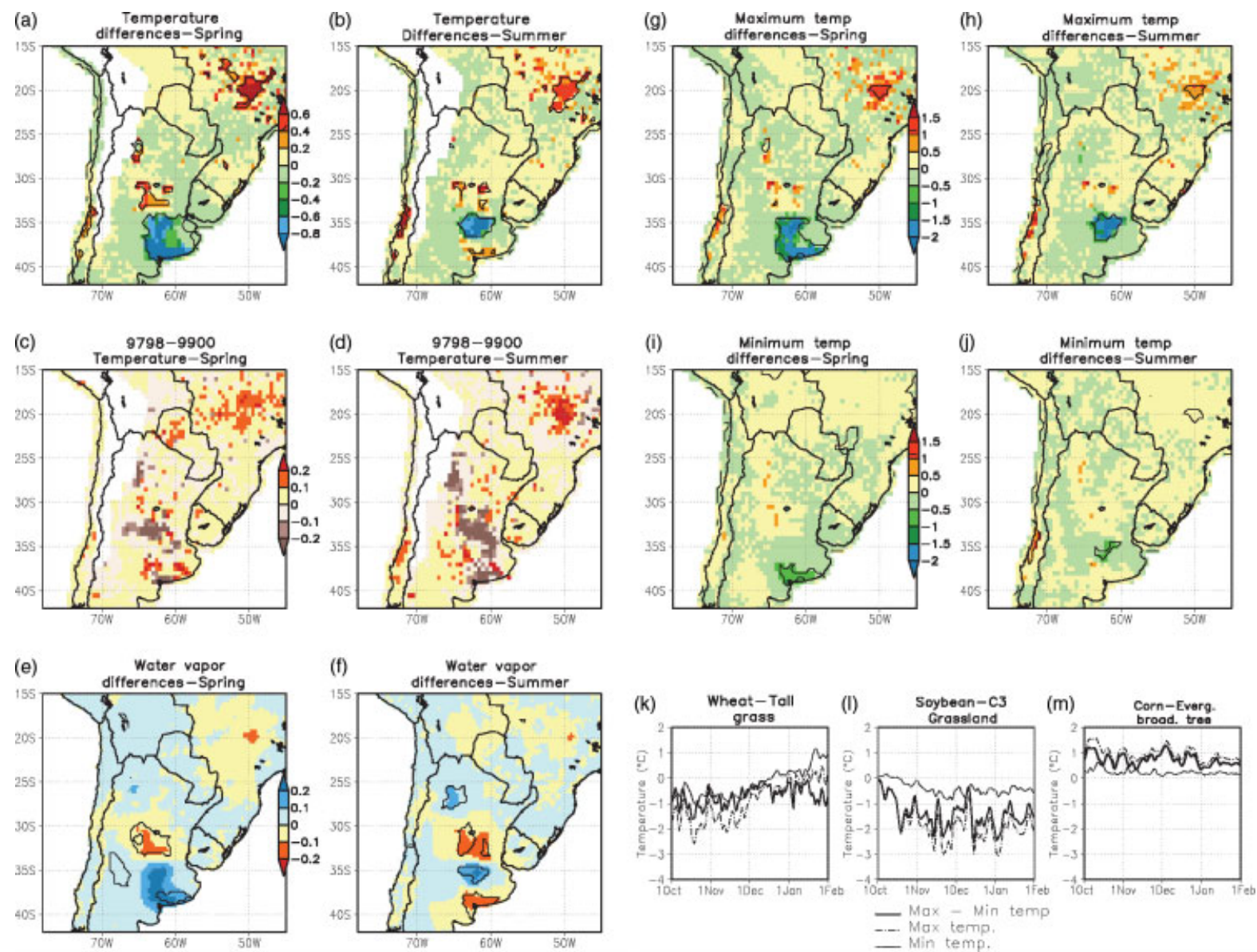

Figure 3. (a) Two-metre temperature $\left({ }^{\circ} \mathrm{C}\right)$ differences CTRL - NAT for spring averaged for the three simulated periods; (b) Idem (a) for summer. (c) Differences between 1997-1998 and 1999-2000 of temperature CTRL - NAT changes for spring; (d) Idem (c) for summer. (e) Water vapor mixing ratio $\left(\mathrm{g} \mathrm{kg}^{-1}\right)$ differences CTRL - NAT for spring averaged for the three simulated periods; (f) Idem (l) for spring. (g) Two-metre maximum (15 Local Standard Time, LST) temperature $\left({ }^{\circ} \mathrm{C}\right)$ differences between CTRL - NAT for spring averaged for the three simulated periods; (h) Idem (g) for summer. (i) Idem (g) for minimum (06 LST) temperature $\left({ }^{\circ} \mathrm{C}\right)$; (j) Idem (i) for summer. (k) Temporal series of two-metre maximum, minimum and their differences (i.e., diurnal temperature range) for wheat - tall grass conversion; (l) Idem (k) for soybean - $\mathrm{C}_{3}$ grassland. (m) Idem (k) for corn - evergreen broadleaf tree. Contoured are the differences with statistical significance greater than 95\%, in (a),

(b) and (e) to (j). This figure is available in colour online at wileyonlinelibrary.com/journal/joc

wetter than the neighboring grasslands. After the wheat has been harvested, the temperature becomes warmer. Similarly, Ge (2010) over Oklahoma and Kansas wheat areas, found that during the growing season wheat was $2.3^{\circ} \mathrm{C}$ cooler and after harvest was $1.6^{\circ} \mathrm{C}$ warmer than the grasslands.

Changes in water vapor mixing ratio were small and only statistically significant in a few areas with LULCC (Figure 3e), f)). They tended to be consistent with the changes in LH fluxes: a more humid near-surface atmosphere was found with increases in $\mathrm{LH}$ and vice versa.

Interannual variability. The impact of LULCC on near-surface temperature was similar for the extreme ENSO years, 1997-1998 and 1999-2000, and the direction of the changes was the same for both periods and seasons (Figure 3c) and d), and Table III). Spatially the variations closely follow the LH interannual variability map (Figure 2k) and 1)): temperature changes are enhanced concurrently with enhanced LH differences. Similar to LH, the wet or dry conditions affect the temperature response. In the conversions broadleaf tree to corn (conversion 6) and tall grass to wheat (conversion 1), wetter conditions amplified the temperature CTRL-NAT differences (Table III). In the centre of the domain, the response is augmented during relatively dry conditions in 1999-2000 (Table III). The patterns are consistent during both seasons, slightly more spatially coherent during summer.

Diurnal variation. Temperature changes between current and natural vegetation experienced a diurnal variation. Figure $3 g$ ) to $\mathrm{j}$ ) show the two-metre temperature differences between CTRL and NAT experiments at 15 Local Standard Time (LST) and at 6 LST, which can be assumed to be the maximum and minimum values during the day, respectively. With a shift from grass to crops, maximum temperatures significantly decreased in the southern Pampas during spring and in central Pampas during both seasons (Figure $3 g$ ) and $h$ ), and Figure 4c) and d)). During spring, those changes were collocated with a large decrease of $\mathrm{SH}$ and an increase of LH (Figure 4f), g)). In the southern Pampas, during 

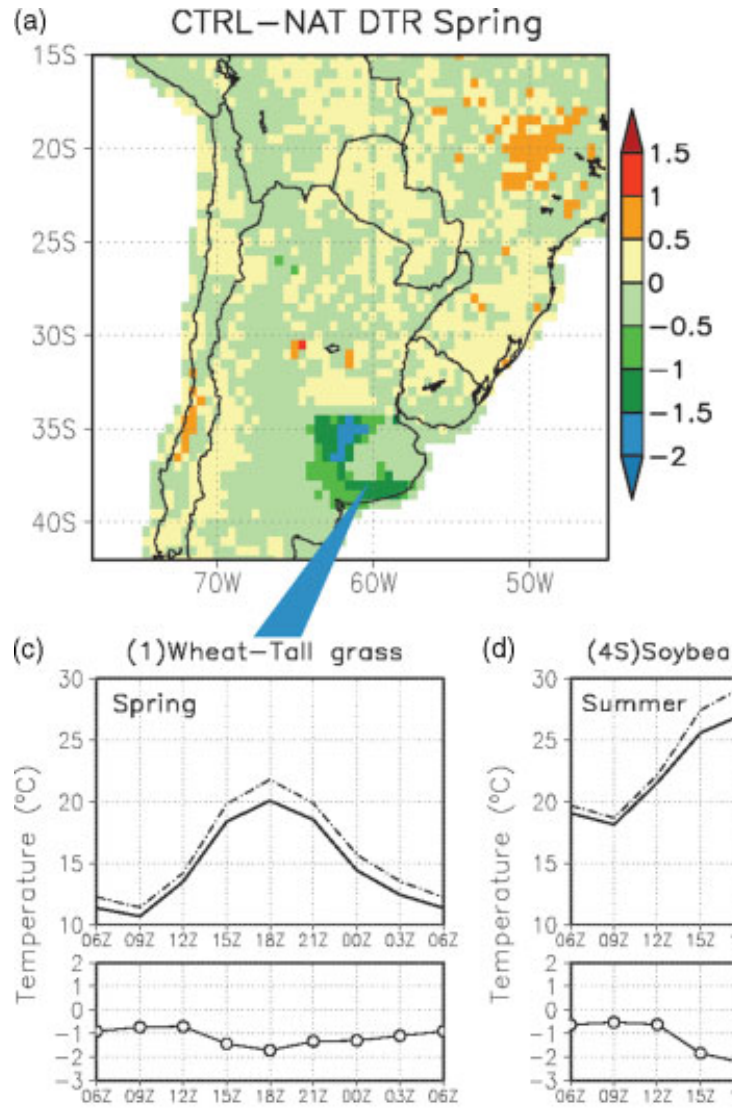

$\longrightarrow$ CTRL (d)

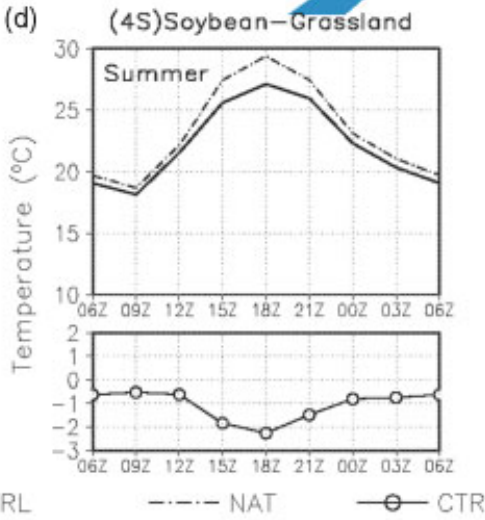

(b) CTRL-NAT DTR Summer

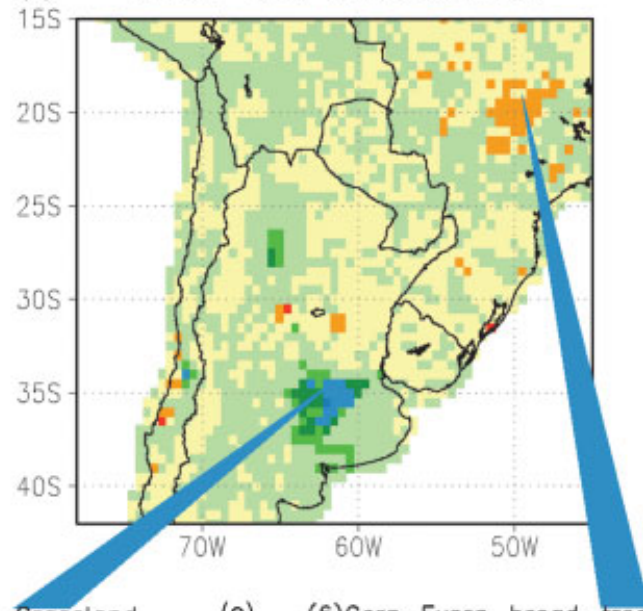

(e) (6)Corn-Everg. broad, tree

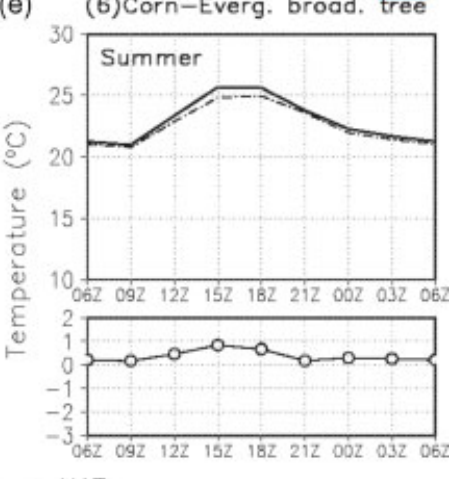

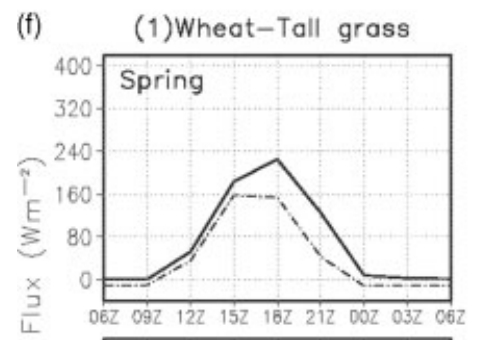

(g) (4S)Soybean-Grassland

(h) (6)Corn-Everg. broad. tree
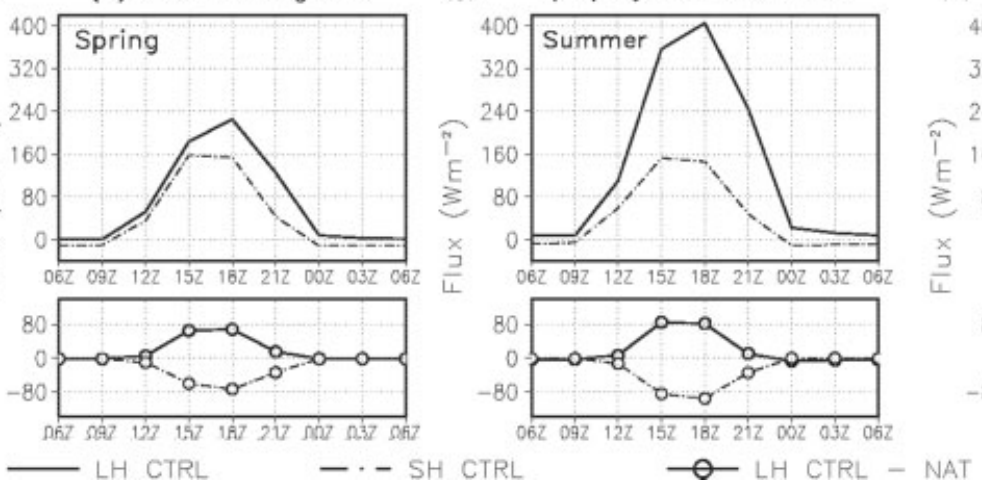
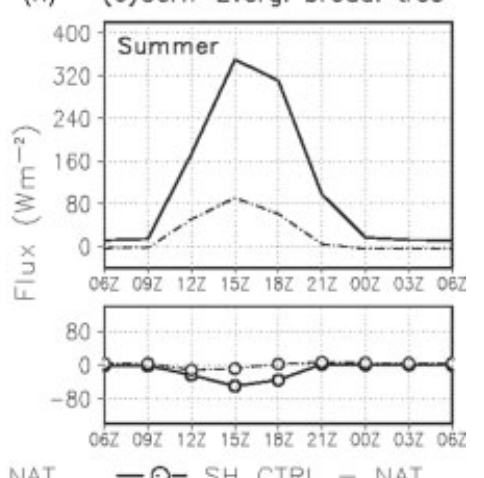

Figure 4. (a) Diurnal temperature range (DTR, ${ }^{\circ} \mathrm{C}$ ) differences CTRL - NAT for spring averaged for the three simulated periods; (b) Idem (a) for summer. (c) Two metre-temperature $\left({ }^{\circ} \mathrm{C}\right)$ averaged for conversion area 1 for CTRL and NAT experiments; the differences CTRL - NAT are shown in the bottom; (d) Idem (c) for conversion area 4S; (e) Idem (c) for conversion area 6. (f) Latent (LH) and sensible heat (SH) fluxes $\left(\mathrm{W} \mathrm{m}^{-2}\right.$ ) averaged for conversion area 1 for CTRL; the differences CTRL - NAT are shown in the bottom; (g) Idem (f) for conversion area 4S; (h) Idem (f) for conversion area 6. This figure is available in colour online at wileyonlinelibrary.com/journal/joc

summer, changes were small and no statistically significant (Figure $3 \mathrm{~h})$ ). In this case, the seasonality of the wheat plays a key role in these differences: the seasonal variation of LAI leads to a shift of the available energy towards transpiration and evaporation in spring.

Maximum temperatures significantly increased in southern Brazil in both seasons where crops (corn) replaced trees and a few cells in Chile and in central Argentina (Figure 3g) and h), and Figure 4e)). These changes can be explained mostly by the daytime decrease in LH (Figure 2i) and j), and Figure 4h)), complemented with a small positive $\mathrm{SH}$ differences
(Figure 2g) and h), and Figure 4h)). Although in an area-averaged basis, daytime $\mathrm{SH}$ is lower over corn and soybean than on evergreen broadleaf trees (conversions 3 and 6 , Table I), there are some corn and soybean grid cells with a slightly higher daytimeaveraged SH than trees. LH shows lower values on crops than on trees starting at 9 LST, reaching maximum averages differences of $60 \mathrm{~W} \mathrm{~m}^{-2}$ at $15 \mathrm{LST}$ (Figure 4h)).

The differences in minimum temperatures were statistically significant only in few grid cells, with cooler 
temperatures in central Argentina and warmer temperatures in central Chile under current vegetation conditions (Figure 3i), j)). Over Oklahoma and Kansas, Ge (2010) also found that at night temperature differences between wheat and adjacent grasslands were smaller, especially after harvest. In summer, there is an overall slight increase in the minimum temperature in the CTRL experiments over much of the simulation domain (Figure $3 \mathrm{j}$ )). In most of the areas, nighttime warming or cooling coincides with areas that experienced also daytime warming or cooling. In some areas, e.g. southern of the Pampas in summer, slight nighttime warming coincides with slight daytime cooling (Figure $3 \mathrm{j}$ )). That extra warming is supplied by a slight increase of $\mathrm{SH}$ during the night under current vegetation conditions.

Over most of the domain, and particularly in the Pampas, the shift to an agricultural scenario resulted in a decrease in the diurnal temperature range (DTR), i.e. daily maximum minus minimum temperature, especially during spring, because maximum temperatures presented a larger decrease than minimum temperatures (Figure 4a) and b)). As an example for this case, the DTR areaaverage for the wheat-tall grass and soybean- $\mathrm{C}_{3}$ grasslands conversions 1 and $4 \mathrm{~S}$, respectively, are shown in Figure $3 \mathrm{k}$ ) and 1). A seasonal shift in the temperature differences for the conversion area 1 can be seen clearly in Figures 3k) and 4a) and b): the decrease in DTR is due in spring to a larger decrease of maximum temperatures (Figure 4c)), and in summer to a larger increase of minimum temperatures. During summer, DTR differences between CTRL and NAT become smaller (Figures 3k) and 4b)). Figure 3l) (and Figure 4d) for summer) shows that for the soybean- $\mathrm{C}_{3}$ grassland conversion the decrease in DTR was mostly due to lower maximum temperatures under current vegetation conditions. In the northern part of the domain, DTR shows an increase under current vegetation conditions (Figure 4a) and b)) mainly due to a larger increase of maximum temperature than of minimum temperatures (Figure 3m)). Rusticucci and Barrucand (2004) found a negative trend in observed maximum temperatures in summer over the period 1959-1998, especially in the centre of the Pampas region. They also found a strong and generalized increase in minimum temperatures but the simulations showed a slight increase.

Our results in general agree with estimations of the impact of LULCC over Argentina for the period 1961-2000 using the 'observation minus reanalysis' (OMR) differences between the trends in the surface temperature (Nuñez et al., 2008). The OMR differences can be assumed to include in part the effects of the land surface characteristics. On a domain average, they found an average decrease in the OMR diurnal temperature range. Spatially (in an annual basis), the trends were negative in the central part of the domain and positive over the western and northeastern part of Argentina, consistent with our results (except for the slight non-statistically significant increase that we found in the grid cells with a $\mathrm{C}_{4}$ grassland to soybean conversion). The area with the strong decrease in the DTR coincides with the location of the soybean production area in the centre of Argentina.

\subsubsection{LULCC effects on precipitation}

Only the summer precipitation differences for each of the simulated periods are shown in Figure 5 and Table III. Slight changes in precipitation were found between the current and natural scenarios. Changes in precipitation and wind patterns have also been found to be linked to changes in vegetation cover (Kanae et al., 2001; Marshall et al., 2004; Pitman et al., 2004; Pielke et al., 2007). Absolute changes were no more than $10 \mathrm{~mm} \mathrm{month}^{-1}$ for most of the simulation domain; absolute differences between 20 and $30 \mathrm{~mm}$ month $^{-1}$ were found in southern Brazil and in some areas in the Pampas region. In some of the grid cells within those areas, the differences relative to the NAT scenario were between 10 and $20 \%$. Those differences were statistically significant in only few grid cells. An area of precipitation decrease centred on $35^{\circ} \mathrm{S}$, $63^{\circ} \mathrm{W}$ can be seen in all periods, and is approximately collocated with large increases of $\mathrm{LH}$ and decrease of $\mathrm{SH}$ (Figure $2 \mathrm{~h}$ ) and j)). In Brazil, a dipole of precipitation differences appear around $20^{\circ} \mathrm{S}, 50^{\circ} \mathrm{W}$ that coincides an area of slight increase of SH (Figure $2 \mathrm{~h}$ )), associated with grid cells that shifted from trees to crops; these had the largest change in roughness length values (i.e. vegetation conversions 3 and 6 in Table I).

\subsection{LULCC sensitivity experiments: current versus} afforestation scenario

\subsubsection{LULCC effects on vegetation characteristics and near-surface energy fluxes}

Overall, afforestation (AFFOR vs CTRL experiments) led to a decrease in albedo and to increases of LAI and roughness length, except for a small increase in albedo in the areas that shifted from wooded grasslands to evergreen broadleaf trees (Table IV). These are the typical changes in the vegetation characteristics expected when converting from grass or crops to forest (Bonan, 2008).

Only results AFFOR - CTRL for summer are shown in Figure 6 and Table IV. In general, LH and SH fluxes were higher and lower, respectively, in the AFFOR experiment than in the CTRL case (Figure 6a) and Table II). Lower albedo in AFFOR scenario increased the available energy which is mostly used in transpiration and evaporation than in heating the atmosphere due to the higher LAI and deeper rooting depth. Averaging over all those grid cells from October to January, daytime LH flux increased $86 \mathrm{~W} \mathrm{~m}^{-2}$, and $\mathrm{SH}$ decreased $52 \mathrm{~W} \mathrm{~m}^{-2}$, equivalent to 37 and $44 \%$, respectively, relative to $\mathrm{LH}$ and $\mathrm{SH}$ for current land cover. The increase in LH was mostly due to increases in transpiration $\left(98 \mathrm{~W} \mathrm{~m}^{-2}\right.$ or $82 \%$ with respect to the CTRL). Total evaporation, i.e. from soil and leaves, decreased $8 \mathrm{~W} \mathrm{~m}^{-2}$ (10\%) mainly because of the decrease in soil evaporation. More energy was used in transpiration than in heating the atmosphere in the afforested scenario and therefore mean $\beta$ for the 

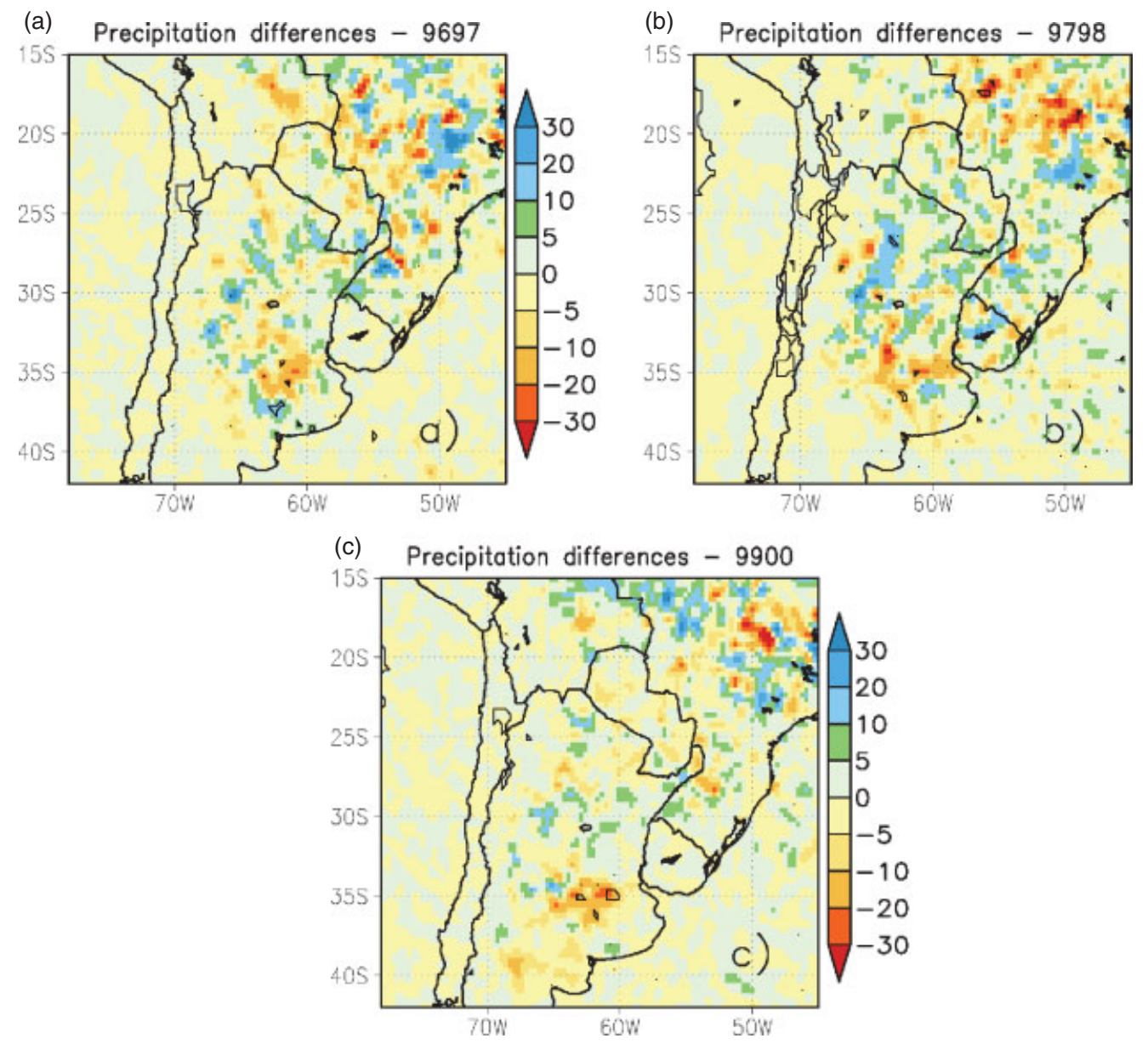

Figure 5. (a) Summer precipitation differences (mm month ${ }^{-1}$ ) CTRL - NAT for 1996-1997; (b) Idem (a) for 1997-1998. (c) Idem (a) for 1999-2000. Contoured are the differences with statistical significance greater than 95\%. This figure is available in colour online at wileyonlinelibrary.com/journal/joc

Table IV. Summer changes (AFFOR-CTRL) of roughness length $\left(z_{0}, \mathrm{~cm}\right)$, albedo $\left(\alpha\right.$, unitless), leaf area index $\left(\mathrm{LAI}, \mathrm{m}^{2} \mathrm{~m}^{-2}\right)$, latent $(\mathrm{LH})$ and sensible $(\mathrm{SH})$ heat fluxes $\left(\mathrm{W} \mathrm{m}^{-2}\right)$, Bowen ratio relative changes $(\beta, \%)$, two-metre temperature $\left(2 \mathrm{mt},{ }^{\circ} \mathrm{C}\right)$ and precipitation $(\mathrm{PR}, \mathrm{mm})$ averaged for each of the vegetation conversions. The second column is the percentage of grid cells $(\%)$ with the vegetation conversion, with respect to the total number of grid cells that experienced a vegetation change. The vegetation in the AFFOR experiment is Evergreen broadleaf tree.

\begin{tabular}{|c|c|c|c|c|c|c|c|c|c|c|c|c|c|c|c|}
\hline \multirow{2}{*}{$\begin{array}{l}\text { Current } \\
\text { vegetation }\end{array}$} & \multirow[t]{2}{*}{$\%$} & \multicolumn{8}{|c|}{ Average } & \multicolumn{3}{|c|}{$1997-1998$} & \multicolumn{3}{|c|}{ 1999-2000 } \\
\hline & & $z 0$ & $\alpha$ & LAI & $\mathrm{LH}$ & $\mathrm{SH}$ & $\beta$ & $2 \mathrm{mt}$ & PR & $\mathrm{LH}$ & $2 \mathrm{mt}$ & PR & $\mathrm{LH}$ & $2 \mathrm{mt}$ & PR \\
\hline Wooded grasslands & 29 & 1.49 & -0.022 & 1.2 & -1 & 12 & 21 & -0.2 & 12 & -6 & 0.1 & 13 & 7 & -0.4 & 8 \\
\hline Soybean & 28 & 1.90 & -0.042 & 0.3 & 89 & -48 & -57 & -0.6 & 0 & 14 & -0.1 & 2 & 151 & -1.0 & -4 \\
\hline Short grass & 28 & 1.98 & -0.070 & 2.8 & 117 & -57 & -68 & -0.7 & 19 & 32 & -0.1 & 8 & 165 & -1.0 & 18 \\
\hline Tall grass & 15 & 1.90 & 0.007 & 2.5 & 137 & -114 & -80 & -0.7 & 2 & 76 & -0.3 & 14 & 182 & -1.0 & 4 \\
\hline
\end{tabular}

converted grid cells decreased from 0.50 in the CTRL case to 0.20 in the afforested scenario (Table IV).

This behaviour was found in most of the grid cells with the land-cover changes, except in some that converted from wooded grasslands, although the differences were not statistically significant. In this case, area-averaged $\mathrm{SH}$ and LH were slightly higher and lower, respectively, in the afforested case than in CTRL, in spite of the higher LAI (Table IV). Nearly half those grid cells showed a slightly higher canopy conductance for the wooded grasslands than the broadleaf trees, resulting in higher LH values in the CTRL scenario.

Figure 6b) shows the summer LH differences between the 1997-1998 and 1999-2000 simulations. The spatial pattern and the direction of the change were similar between both periods, but the values showed a large interannual variability. In the wet 1997-1998 summer (Figure A. 1 in the Appendix) the LULCC yielded a weaker signal in the LH flux compare to the dry 1999-2000 period: LH differences AFFOR-CTRL averaged over the land-cover 

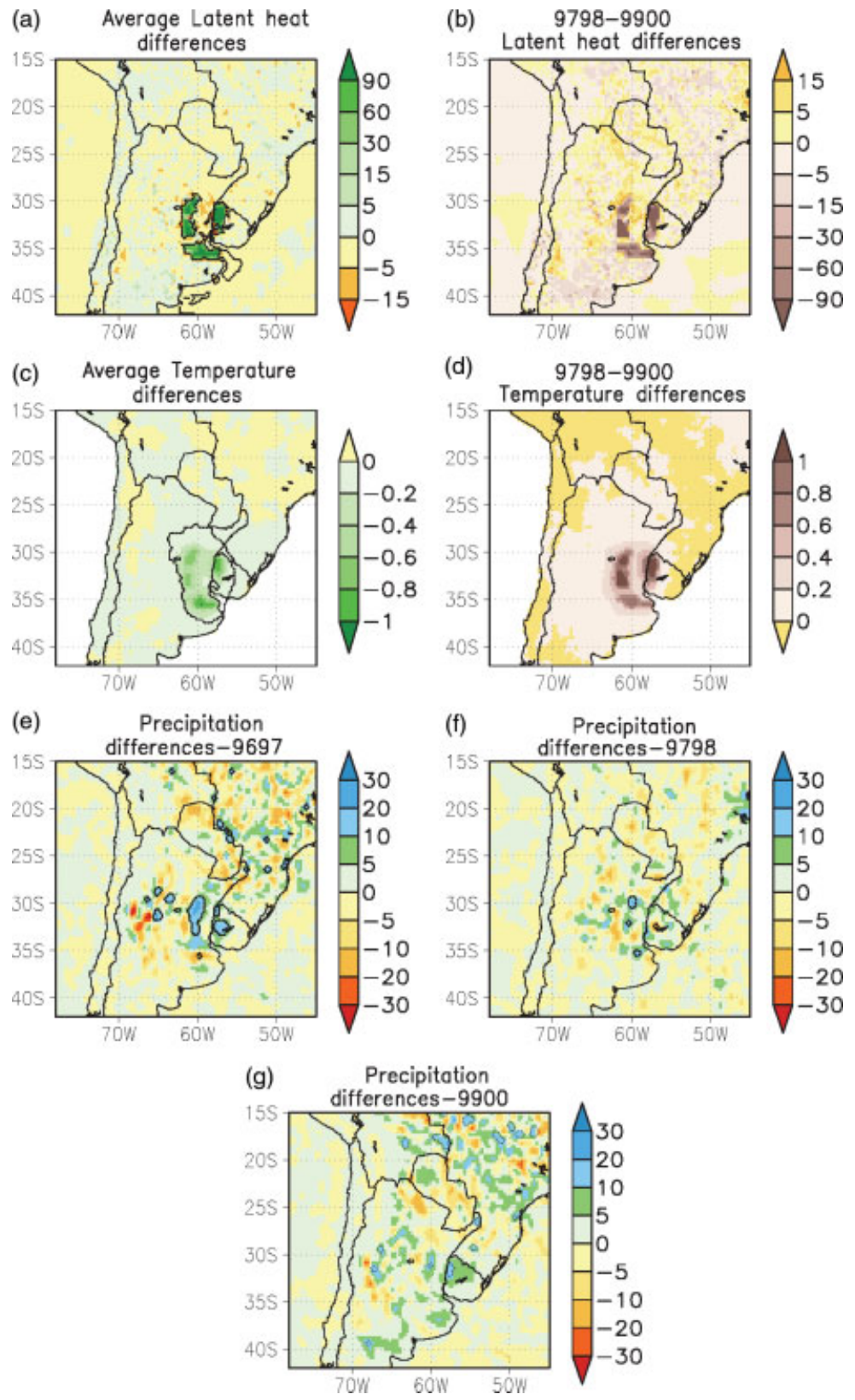

Figure 6. (a) Summer averaged differences AFFOR - CTRL for latent heat $\left(\mathrm{W} \mathrm{m}^{-2}\right)$. (b) Differences between 1997-1998 and 1999-2000 of latent heat $\left(\mathrm{W} \mathrm{m}^{-2}\right)$ AFFOR - CTRL for summer. (c) Idem (a) for temperature $\left({ }^{\circ} \mathrm{C}\right)$. (d) Idem (b) for temperature. (e) Summer precipitation differences (mm month ${ }^{-1}$ ) AFFOR - CTRL for 1996-1997; (f) Idem (e) for 1997-1998. (g) Idem (e) for 1999-2000. Contoured are the differences with statistical significance greater than $95 \%$. This figure is available in colour online at wileyonlinelibrary.com/journal/joc

changed areas were $29 \mathrm{~W} \mathrm{~m}^{-2}$ in 1997-1998 versus $126 \mathrm{~W} \mathrm{~m}^{-2}$ in 1999-2000 (Table IV). Moreover, during 1997-1998 SH differences reversed its direction in the grid cells that shifted from shortgrass (and from soybean in some grid cells): average $\mathrm{SH}$ was $24 \mathrm{~W} \mathrm{~m}^{-2}$ during 1997-1998 versus -97 $\mathrm{Wm}^{-2}$ during 1999-2000 (not shown). LH differences were small but still positive during 1997-1998 in those grid cells. The model simulated similar and slightly lower canopy conductance in the shortgrass and soybean grid cells in the CTRL scenario than in the AFFOR scenario, leading to a weak response in the LH fluxes.

During the dry 1999-2000 summer, the grid cells that converted from wooded grasslands showed a small positive area-averaged LH differences AFFOR-CTRL similar to the rest of the converted grid cells. In this case, a combination of the deeper root system and slightly higher canopy conductance of broadleaf trees compared to the wooded grasslands enhanced the response of LH fluxes to dry conditions.

\subsubsection{LULCC effects on near-surface temperature, humidity and precipitation}

As expected from the changes in near-surface fluxes, afforestation led to cooler and wetter near-surface atmospheric conditions over most of the afforested grid cells (Figure 6c)). Area-averaged first level temperature differences between afforested and current conditions were 
$-0.6^{\circ} \mathrm{C}$ and $-0.8^{\circ} \mathrm{C}$ in spring and summer, respectively. Temperature changes were statistically significant except for the grid cells that shifted from wooded grasslands consistent with the weak impact found in the $\mathrm{LH}$ and $\mathrm{SH}$ values.

Modelling simulations and observational studies showed similar results to the land-cover changes simulated in this study. For a location very close to the area with the LULCC in this study, Nosetto et al. (2005), using estimations from Landsat 7 ETM+ images, found increases in LH and decreases in temperature of around $5{ }^{\circ} \mathrm{C}$. Higher evaporation and transpiration rates in forest compared to grasslands were also found in other observational studies (e.g. Hodnett et al., 1995). Strack et al. (2008), using RAMS in an eastern US domain, found a slight decrease in the June temperature since 1920 due to regrowth of forest in some areas.

Figure 6d) shows the summer temperature differences AFFOR-CTRL between the 1997-1998 and 1999-2000 simulations. Similar to LH and SH interannual behaviour, temperatures changes were influenced by the different atmospheric conditions in those two extreme ENSO years. The lower LH differences in 1997-1998 than in 1999-2000 (Table IV) led to lower temperature differences AFFOR-CTRL during the wet summer period of 1997-1998. The largest summer temperature difference AFFOR-CTRL was $-1.4^{\circ} \mathrm{C}$ during $1999-2000$ and $-0.5^{\circ} \mathrm{C}$ during $1997-1998$. During the latter period, the direction of the temperature signal reversed in the grid cells that shifted from shortgrass (and from soybean in some grid cells), consistent with the LH and SH patterns described before: although small, temperature differences AFFOR-CTRL were positive, of up to $0.1^{\circ} \mathrm{C}$ in some of those grid cells. This is the area associated with the largest interannual variability (Figure 6d)).

Higher LH under an AFFOR scenario increased the amount of water vapour in the lower atmosphere (not shown). Area-average summer differences were $0.5 \mathrm{~g} \mathrm{~kg}^{-1}$ with values of up to $0.7 \mathrm{~g} \mathrm{~kg}^{-1}$ in grid cells that shifted from shortgrass. Interannual differences follow the LH behaviour: AFFOR-CTRL differences were enhanced in the dry summer period 1999-2000.

Changes in precipitation were more noticeable in summer (Figure 6e) to g)). The largest changes tended to coincide with the grid cells that experienced the vegetation changes, but the LULCC signal on precipitation were found throughout the simulation domain. For the summer of 1996-1997, absolute values in the afforested scenario were up to $30 \mathrm{~mm}$ month $^{-1}$ higher than for CTRL (Figure 6e)). During the dry summer of 1999-2000, the absolute differences were in general smaller than in 1996-1997 (Figure 6g)), but the relative changes were larger, up to $30 \%$ in $1999-2000$ compared to the CTRL. The differences AFFOR-CTRL tended to be lower in the relatively wet 1997-1998 summer period (Figure 6f)). The spatial pattern of the precipitation changes was associated with changes in moisture convergence (due to changes in roughness length and displacement height) and in LH (not shown).

\section{Summary and conclusions}

A coupled atmospheric-vegetation regional model, GEMRAMS, is used to examine how the changes in vegetation could potentially affect the near-surface energy balance, temperature, humidity, and precipitation over a southern South America domain during spring-mid-summer. Land cover scenarios representing current (i.e. agricultural landscape), natural (i.e. before European settlement), and afforestation conditions were implemented for this region. Three spring-summer periods were selected based on their ENSO classification to report differences in the LULCC impacts during distinct large-scale conditions.

The simulated impacts of the land cover changes on the near-surface atmosphere were the ones expected based on changes in physical and physiological parameters. The increase shift to agriculture resulted in a generalized deerease in albedo, reducing the available energy at the near-surface atmosphere. The partitioning of the energy between LH and SH fluxes changed (as shown in Bowen ratio value), leading to distinct near-surface atmosphere temperature responses. The potential effect of agriculture was cooling, when the shift was from $\mathrm{C}_{3}$ grasses to crops, concurrent with a decrease in $\mathrm{SH}$ and an increase in LH fluxes associated with an increase in LAI; warming occurred when crops replaced $\mathrm{C}_{4}$ grasses, wooded grasslands, or trees, due to a decrease in $\mathrm{LH}$ (related to a decrease in LAI) and a small increase in SH. These results compare well with other modelling studies addressing the shift to agriculture using regional climate models (e.g. Baidya Roy et al., 2003, Marshall et al., 2004 and Strack et al., 2008 for a North American domain; Narisma and Pitman, 2003, and Pitman et al., 2004 for Australia; MacKellar et al., 2008 for southern Africa; Wang et al., 2003 for China; Douglas et al., 2009 for India), and global models (e.g. Bounoua et al., 2002; Lawrence and Chase, 2010).

Our results show a diurnal variation in the temperature changes. In the southern and central Pampas we found a significant decrease in maximum temperatures during spring and summer of up to $-2.1{ }^{\circ} \mathrm{C}$ in some grid cells. Minimum temperatures also significantly decreased in these areas, but in fewer number if grid cells; a nonsignificant increase appears in summer in the southern Pampas. This led to a decrease in the diurnal temperature range in this area. Conversely, maximum and minimum temperatures increased in Brazil, Chile, and central and northwest Argentina; the larger increase in maximum temperature led to an increase in the northern part of the domain. Basing on the observational studies of Rusticucci and Barrucand (2004) and Nuñez et al. (2008), our results suggest a potential strong influence of LULCC on the maximum temperatures in central Argentina in summer.

An afforestation scenario also modified near-surface fluxes and temperature. From October to January, 
afforested grid cells had higher LH and cooler temperatures than the ones under current vegetation cover (mainly grasslands). Higher values of LAI, higher efficiency in water transfer from the soils, and a deeper root system were the vegetation characteristics associated with those changes.

Precipitation was also affected by the vegetation changes, although the absolute values were not very large. Changes in rainfall were associated with changes in $\mathrm{LH}$, roughness length, and areas of moisture convergence. In general, dry conditions tended to enhance the LULCC signal on precipitation. For example, changes were relatively higher for the dry summer of 1999-2000.

These sensitivity experiments illustrate that the type of vegetation involved in the conversions was important in determining the sign of the LULCC impacts. For example, in the soybean grid cells in the current vegetation, the temperature response was cooling when the conversion was from $\mathrm{C}_{3}$ grasslands and slight warming when the shift was from $\mathrm{C}_{4}$ grasslands. Also, for the afforestation case, some grid cells showed no change or even slight warming in one of the simulated periods when the shift was from wooded grasslands. In agreement with other studies, our results show the importance of including the physiological processes when assessing the LULCC impacts (i.e. Eastman et al. 2001).

The experiments also showed that spatial and temporal variability are important. For example, during the spring-mid-summer period, harvest takes place for wheat and sowing occur for soybean and corn. After wheat harvest, a drastic change in vegetation takes place that affected LAI and albedo, and the response of temperature and humidity to LULCC becomes of opposite sign.

The impacts were mostly limited to the areas of the land-cover changes although a large spatial and temporal variability can be found associated with different circulation patterns during the two ENSO extreme years in areas that were not collocated with the LULCC. These modelling simulations show that interannual variability, particularly related to precipitation conditions, is important when assessing the strength of the impact, although these patterns cannot be considered conclusive because only two extreme ENSO years were considered. In most of the cases the direction of the signal remained the same, but the strength of the signal depended on how the general precipitation conditions affected the vegetation types involved in the changes. In some cases, the signal was enhanced during a dry period (e.g. centre of the Pampas, summer 1999-2000) and in other cases it was enhanced during a wet period (e.g. broadleaf to corn conversion in Brazil, year 1997-1998). The ENSO signal on precipitation in this region presents a large spatial heterogeneity and also a large intraseasonal variability (e.g. Penalba et al., 2005). As a result, the seasonal characteristics of atmospheric conditions and precipitation interact with the type of land-cover change involved (that has distinct seasonal variations) in modulating the near-surface atmosphere's response to those LULCC. Multiyear simulations, for example, using the complete ERA-40 data as lateral boundary conditions, would provide a larger set of simulations experiments from where the effects of the long-term climate variability on LULCC could be evaluated. We are deferring these experiments for a later study.

Some questions still remain. Here, we have only simulated one current land-cover/land-use map. How much are our results affected by the current land-cover map? Some of the grid cells with annual crops may actually correspond to a mixture with pastures or a mixture of winter and summer crops, i.e. double-cropping winter wheat with soybeans (Guerschman et al., 2003), a common cropping strategy in the Pampas. In this case, the change in LAI after the wheat harvest might not be as sharp as we assumed in the simulations and, therefore, the response in temperature may be dampened. The soybean expansion on the NW and NE Argentina was only marginally considered, and additional areas of LULCC might exist with a shift from trees or wooded grasslands to summer crops. Large areas of forest in Paraguay and Bolivia have been cleared due to agriculture expansion but we have not considered those areas. Also, increasing the afforested area would increase the area of cooling and the effect on precipitation might also be more noticeable (e.g. Pitman and Narisma, 2005). However, 'realistic' landcover scenarios were addressed in the afforestation scenario.

How much are these simulations affected by the landsurface LEAF2-GEMTM scheme? For example, Oleson et al. (2004) found that parameterisation of transpiration and evaporation processes affected the impact of landcover changes on temperature. Pitman et al. (2009) found a large variability in the LULCC signals among several global climate models. A variety of regional atmospheric models coupled with different land-surface schemes could be applied to the southern South America domain.

In these simulations we have not included additional forcing and processes, like the global increased in greenhouse gases, and direct and indirect aerosols effects that can also affect the near-surface atmosphere, and could also interact with LULCC. The effects of LULCC and a double $\mathrm{CO}_{2}$ scenario (with their interactions) on the near-surface atmosphere for a similar simulation domain and setup are presented in Beltrán (2005) and BeltránPrzekurat et al. (2010). We have not intended to simulate the long-term changes in temperature and precipitation that have occurred in the region.

This study constitutes a new regional assessment of the impacts of anthropogenic changes on climate (NRC, 2005). Some of the areas within the simulation domain have the highest rates of LULCC in the world (Baldi and Paruelo, 2008; Grau et al., 2005), and the land-cover changes in the region are far from over. Projections for Argentina, Uruguay, and southern Brazil suggest that the agricultural area would keep its increasing trend 
and that afforestation would continue in Uruguay and partially in Argentina. The LULCC assumed in these simulations have led to complex interactions between the biophysical and physiological characteristics of the land and between the vegetation and the near-surface energy fluxes. Modification of the biological component of the climate system significantly affects near-surface atmosphere, and it must be included in regional and global studies of human influences on climate variability and change.

\section{Acknowledgments}

ECMWF ERA-40 data used in this study/project have been obtained from the ECMWF data server. Support for Roger A. Pielke Sr was provided by CIRES/ATOC and the Vice Chancellor for Research at the University of Colorado at Boulder. Support for Adriana BeltránPrzekurat was provided by the U.S. National Science Foundation (Grant ATM-0831331). We would like to thank Dallas Staley for her contribution in editing and finalising the paper.
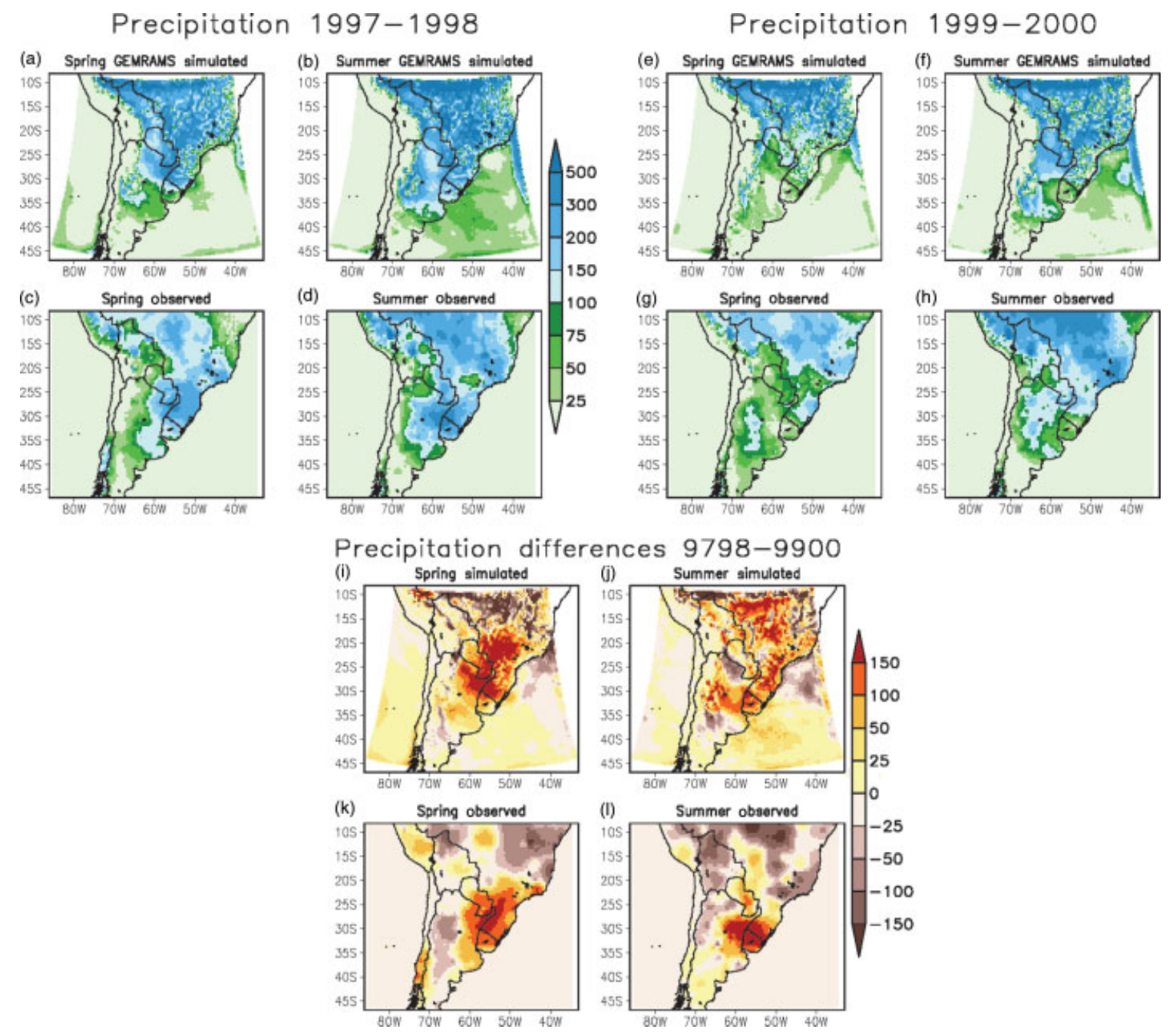

Figure A.1. (a to d) Mean spring and summer precipitation (mm month ${ }^{-1}$ ) for 1997-1998 period: (a, b) simulated CTRL, (c, d) observed. (e to h) Idem (a to b) for 1999-2000 period. (i to 1): Spring and summer precipitation differences between 1997-1998 and 1999-2000 periods : (i, j) simulated CTRL; $(\mathrm{k}, \mathrm{l})$ observed. This figure is available in colour online at wileyonlinelibrary.com/journal/joc 

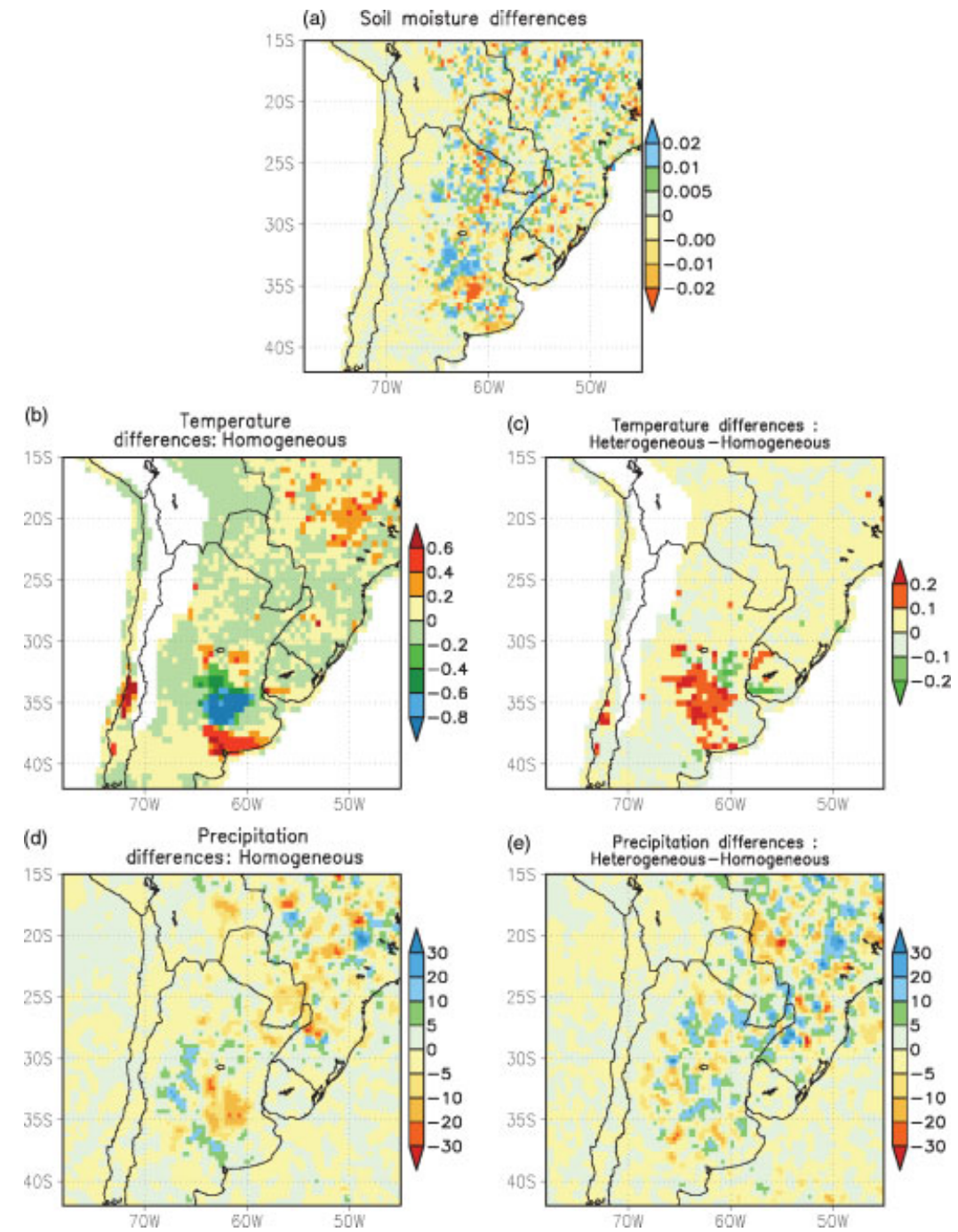

Figure A.2. (a) Initial differences in volumetric soil moisture content $\left(\mathrm{m}^{3} \mathrm{~m}^{-3}\right)$ CTRL - CTRLh. (b) Summer temperature differences $\left({ }^{\circ} \mathrm{C}\right)$ CTRLh - NATh. (c) Summer temperatures differences (CTRLNAT) - (CTRLh - NATh). CTRLh, NATh: CTRL and NAT experiments with homogeneous initial soil moisture conditions respectively. (d) Idem (b) for precipitation $\left(\mathrm{mm} \mathrm{month}^{-1}\right.$ ). (e) Idem (c) for precipitation $\left(\mathrm{mm} \mathrm{month}{ }^{-1}\right)$. This figure is available in colour online at wileyonlinelibrary.com/journal/joc

Brazil and in the western part of the domain collocated with the highest elevation (Figure A.1i) to A.11)). This pattern of interannual variability is best simulated during the spring and for the area south of $25-20^{\circ} \mathrm{S}$. In the northeastern part of the domain the reverse pattern is simulated especially during summer reflecting the abovementioned underestimation of precipitation in this area (Figure A.1b) and f)). The largest positive area is centred in the central-eastern Argentina, Uruguay, and southern Brazil, indicating a drier spring-summer 1999-2000 compared to 1997-1998.

\section{A.2. LULCC Sensitivity to Initial Soil Moisture Conditions}

Soil moisture initialisation can influence the LULCC impacts on temperature and precipitation. Koster et al. (2009) showed that an appropriate scaling is needed when using soil moisture data from one model to another to correctly address the unique nature of the modelled soil moisture. An additional pair of CTRL and NAT simulations for the 1996-1997 period was performed to analyse the sensitivity of the LULCC impacts to initial soil moisture conditions (Figure A.2). The experiments, CTRLh and NATh, were initialized with a horizontally and vertically homogeneous $50 \%$ of saturation volumetric soil moisture content. Figure A.2a) shows the initial volumetric soil moisture content differences between the originals and these additional experiments, averaged through the first $1 \mathrm{~m}$. Summer temperature differences CTRLh-NATh showed a similar pattern to the CTRLNAT simulations (Figure 3b)): a large area of cooling in the centre of the domain surrounded by areas of warming. The differences were mostly within $\pm 0.2^{\circ} \mathrm{C}$ with respect to the heterogeneous conditions (Figure A.2c)). Wetter initial conditions tended to lessen the temperature response to LULCC and drier initial conditions tended to amplify it.

Summer precipitation differences CTRLh-NATh are shown in Figure A.2d). The spatial pattern is very similar 
to the original experiments (Figure 4a)). The differences between these two experiments (Figure A.2e)) show a very noisy field, but the effect of soil moisture initial conditions were of same magnitude than the response of the precipitation to the LULCC (Figures 4a) and A.2d)). The impact appeared all over the simulation domain, not only in the areas affected by LULCC. High initial soil water content decreases the differences in precipitation due to LULCC in some areas; for example, in the area centred on $32^{\circ} \mathrm{S}, 62^{\circ} \mathrm{W}$, wetter initial conditions in the CTRL and NAT experiments (Figure A.2a)) led to smaller precipitation differences than in the CTRLhNATh experiments (Figure 4a) vs Figure A.2d)). In other areas, wetter conditions might reverse the signal of the response. For example, in a small area centred on $20^{\circ} \mathrm{S}$, $55^{\circ} \mathrm{W}$, drier initial conditions in the CTRL and NAT than in the CTRLh and NATh experiments led to a negative CTRL-NAT precipitation response (Figure 4a)) versus a positive CTRLh-NATh response (Figure A.2d)).

Although our results showed that the sensitivity to initial soil moisture conditions are not too large in the case of temperature, i.e. within $\pm 0.2^{\circ} \mathrm{C}$, differences can be as large as the LULCC impacts in the case of precipitation. This issue could also be addressed by increasing the number of simulated periods.

\section{References}

Aceituno P. 1988. On the functioning of the Southern Oscillation in South America, Part I: Surface Climate. Monthly Weather Review 116: $505-524$.

Adegoke JO, Pielke Sr RA, Eastman J, Mahmood R, Hubbard KG. 2003. Impact of irrigation on midsummer surface fluxes and temperature under dry synoptic conditions: A regional atmospheric model study of the U.S. High Plains. Monthly Weather Review 131: 556-564.

Baidya Roy S, Avissar R. 2002. Impact of land use/land cover change on regional hydrometeorology in Amazonia. Journal of Geophysical Research 107: DOI:10.1029/2000JD000266.

Baidya Roy S, Hurtt GC, Weaver CP, Pacala SW. 2003. Impact of historical land cover change on the July climate of the United States. Journal of Geophysical Research 108(D24): 4793, DOI:10.1029/2003JD003565.

Baldi G, Paruelo JM. 2008. Land-use and land-cover dynamics in South American temperate grasslands. Ecology and Society 13: 6. http://www.ecologyandsociety.org/vol13/iss2/art6/.

Beltrán AB. 2005. Using a coupled biospheric-atmospheric modeling system (GEMRAMS) to model the effects of land-use/landcover changes on the near surface atmosphere, PhD. Dissertation, Colorado State Univ., Fort Collins, Colorado. p. 186. http://pielkeclimatesci.files.wordpress.com/2009/09/beltranphd.pdf.

Beltrán-Przekurat A, Pielke Sr RA, Eastman JL, Narisma GT, Pitman AJ, Lei M, Niyogi D. 2010. Using the Factor Separation Method for land-use land-cover change impacts on weather and climate process with the Regional Atmospheric Modeling System. In: The Factor Separation Method in the Atmosphere-Applications and Future Prospects, Alpert P and Sholokhman T (eds). Cambridge University Press: New York; 292 pp.

Betts RA, Falloon PD, Goldewijk KK, Ramankutty N. 2007. Biogeophysical effects of land use on climate: Model simulations of radiative forcing and large-scale temperature change. Agricultural and Forest Meteorology. 142: 216-233.

Boletta P, Ravelo A, Planchuelo A, Grilli M. 2006. Assessing deforestation in the Argentine Chaco. Forest Ecology and Management 228: 114-118.

Bonan GB. 2008. Forests and Climate Change: Forcings, Feedbacks, and the Climate Benefits of Forests. Science, 320: 1444-1449, DOI:10.1126/science.1155121.

Bounoua L, DeFries RS, Collatz GJ. 2002. Effects of land cover conversion on surface climate. Climate Change 52: 29-64.
Buermann W, Wang Y, Dong J, Zhou L, Zeng X, Dickinson RE, Potter CS, Myneni RB. 2002. Analysis of a multiyear global vegetation leaf area index data set. Journal of Geophysical Research 107: 4646. 10.1029/2001JD000975.

Camilloni I, Barros V. 2000. The Paraná River response to El Niño 1982-83 and 1997-98 Events. Journal of Hydrometeorology 1: 412-430.

Chen D-X, Coughenour MB. 1994. GEMTM: a general model for energy and mass transfer of land surfaces and its application at the FIFE sites. Agricultural and Forest Meteorology 68: 145-171.

Chen D-X, Coughenour MB. 2004. Photosynthesis, transpiration, and primary productivity: scaling up from leaves to canopies and regions using process models and remotely sensed data. Global Biogeochemical Cycles. 18: GB4033, DOI:10.1029/2002 GB001979.

Chen D-X, Coughenour MB, Knapp AK, Owensby CE. 1994. Mathematical simulation of $\mathrm{C}_{4}$ grass photosynthesis in ambient and elevated $\mathrm{CO}_{2}$. Ecological Modelling 73: 63-80.

Correia FWS, Alvalá RCS, Manzi AO. 2007. Modeling the impacts of land cover change in Amazônia: a regional climate model (RCM) simulation study. Theoretical and Applied Climatology, DOI:10.1007/s00704-007-0335-z.

Costa MH, Yanagi SNM, Souza PJOP, Ribeiro A, Rocha EJP. 2007. Climate change in Amazonia caused by soybean cropland expansion, as compared to caused by pastureland expansion. Geophysical Research Letters 34: DOI:10.1029/2007GL029271.

Cotton WR, Pielke Sr RA, Walko RL, Liston GE, Tremback G, Jiang H, McAnelly RL, Harrington JY, Nicholls ME, Carrio GG, McFadden JP. 2003. RAMS 2001: current status and future directions. Meteorology and Atmospheric Physics 82: 5-29.

Davin EL, de Noblet-Ducoudré N. 2010. Climatic Impact of GlobalScale Deforestation: Radiative versus Nonradiative Processes. Journal of Climate 23: 97-112.

Douglas EM, Beltrán-Przekurat A, Niyogi D, Pielke Sr RA, Vörösmarty CJ. 2009. The impact of agricultural intensification and irrigation on land-atmosphere interactions and Indian monsoon precipitation - A mesoscale modeling perspective. Global and Plane tary Change 67: 117-128, DOI:10.1016/j.gloplacha.2008.12.007.

Douglas EM, Niyogi D, Frolking S, Yeluripati JB, Pielke Sr RA, Niyogi N, Vörösmarty CJ, Mohanty UC. 2006. Changes in moisture and energy fluxes due to agricultural land use and irrigation in the Indian monsoon belt. Geophysical Research Letters 33: DOI:10.1029/2006GL02655.

Eastman JL, Coughenour MB, Pielke Sr RA. 2001. The regional effects of $\mathrm{CO}_{2}$ and landscape change using a coupled plant and meteorological model. Global Change Biology 7: 797-815.

FAO. 2001. Global Forest Resources Assessment 2000. FAO Forestry Paper 140. Rome, Food and Agriculture Organization. http://www.fao.org/forestry/fo/fra/.

FAO. 2004. Statistical yearbook. Rome, Italy. Food and Agriculture Organization of the United Nations, 2004. p. 330.

Ge J. 2010. MODIS observed impacts of intensive agriculture on surface temperature in the southern Great Plains. International Journal of Climatology, DOI:10.1002/joc.2093.

Georgescu M, Miguez-Macho G, Steyaert LT, and Weaver CP. 2009. Climatic effects of 30 years of landscape change over the Greater Phoenix, Arizona, region: Surface energy budget changes. Journal of Geophysical Research 114: D05110, DOI:10.1029/2008JD010745.

Grau HR, Gasparri NI, Aide TM. 2005. Agriculture expansion and deforestation in seasonally dry forests of northwest Argentina. Environmental Conservation 32: 140-148.

Grimm A, Barros V, Doyle M. 2000. Climate variability in southern South America associated with El Niño and La Niña events. Journal of Climate 13: 35-58.

Guerschman JP, Paruelo JM. 2005. Agricultural impacts on ecosystem functioning in temperate areas of North and South America. Global and Planetary Change 47: 170-180.

Guerschman JP, Paruelo JM, Burke IC. 2003. Land use impacts on the normalized difference vegetation index in temperate Argentina. Ecological Applications 13: 616-628.

Hahmann AN, Dickinson RE. 1997. RCCM2-BATS Model over Tropical South America: Applications to Tropical Deforestation. Journal of Climate 10: 1944-1964.

Hall AJ, Rebella CM, Ghersa CM, Culot JPh. 1992. Field-crop systems of the pampas. In Field Crop Ecosystems, Pearson CJ (ed) Ecosystems of the World: Elsevier, Amsterdam; pp. 413-450.

Hodnett MG, Pimentel da Silva L, da Rocha HR, Cruz Senna R. 1995. Seasonal soil water storage changes beneath central Amazonian rainforest and pasture. Journal of Hydrology 170: 233-254. 
Kanae S, Oki T, Musiake K. 2001. Impact of Deforestation on Regional Precipitation over the Indochina Peninsula. Journal of Hydrometeorology 2: 51-70.

Koster RD, Guo Z, Dirmeyer PA, Yang P, Mitchell K, Puma MJ. 2009. On the nature of soil moisture in land surface models. Journal of Climate 22: 4322-4335.

Larcher W. 1995. Physiological Plant Ecology. 3rd edn, SpringerVerlag: p. 506.

Lawrence PJ, Chase TN. 2010. Investigating the Climate Impacts of Global Land Cover Change in the Community Climate System Model (CCSM 3.0). International Journal of Climatology, DOI: $10.1002 /$ joc.2061.

Lu L, Pielke RA, Liston GE, Parton WJ, Ojima D, Hartman M. 2001. Implementation of a two-way interactive atmospheric and ecological model and its application to the central United States. Journal of Climate 14: 900-919.

MacKellar NC, Tadross MA, Hewitson BC. 2008. Effects of vegetation map change in MM5 simulations of southern Africa's summer climate. International Journal of Climatology, DOI:10.1002/joc.1754.

Marshall CH Jr, Pielke Sr RA, Steyaert LT, Willard DA. 2004. The impact of anthropogenic land-cover change on the Florida peninsula sea breezes and warm season sensible weather. Monthly Weather Review 132: 28-52.

McPherson RA, Stensrud DJ, Crawford KC. 2004. The impact of Oklahoma's winter wheat belt on the mesoscale environment. Monthly Weather Review 132: 405-421.

Narisma GT, Pitman AJ. 2003. The impact of 200 years of land cover change on the Australian near-surface climate. Journal of Hydrometeorology 4: 424-436.

Narisma GT, Pitman AJ, Eastman JL, Watterson IG, Pielke Sr. RA, Beltrán-Przekurat A. 2003. The role of biospheric feedbacks in the simulation of the impact of historical land cover change on the Australian January climate. Geophysical Research Letters 30: 2168, DOI:10.1029/2003GL018261.

Nicolini M, Skabar YG, Ulke AG, Saulo AC. 2002. RAMS model performance in simulating precipitation during strong poleward low level jet events over northeastern Argentina. Meteorologica 27 $1-18$.

Nobre CA, Sellers PJ, Shukla J. 1991. Amazonian deforestation and regional climate change. Journal of Climate 4: 957-988.

Nosetto MD, Jobbagy EG, Paruelo JM. 2005. Land-use change and water losses: the case of grassland afforestation across a soil textural gradient in central Argentina. Global Change Biology 11: $1101-1117$.

NRC (National Research Council). 2005. Radiative forcing of climate change: Expanding the concept and addressing uncertainties. The National Academies Press: Washington, DC.

Nuñez MN, Ciapessoni HH, Rolla A, Kalnay E, Cai M. 2008. Impact of land use and precipitation changes on surface temperature trends in Argentina. Journal of Geophysical Research 113: D06111, DOI:10.1029/2007JD008638

Oleson KW, Bonan GB, Levis S, Vertenstein M. 2004. Effects of land use change on U.S. climate: impact of surface datasets and model biogeophysics. Climate Dynamics, DOI:10.1007/s00382-004-04269.

Paruelo JM, Guerschman JP, Verón S. 2005. Expansión agrícola y cambios en el uso del suelo. Ciencia Hoy 87: 14-23.

Paruelo JM, Jobbagy EG, Sala OE, Lauenroth WK, Burke IC. 1998. Functional and structural convergence of temperate grassland and shrubland ecosystems. Ecological Applications 8: 194-206.

Penalba O, Beltrán A, Messina CD. 2005. Monthly rainfall in CentralEastern Argentina and ENSO: A comparative study of rainfall forecast methodologies. Revista Brasileira de Agrometeorología 13: 49-61.

Pielke Sr RA, Adegoke J, Beltrán-Przekurat A, Hiemstra CA, Lin J, Nair US, Niyogi D, Nobis TE. 2007. An overview of regional land use and land cover impacts on rainfall. Tellus B 59: 587-601.

Pielke Sr RA, Marland G, Betts RA, Chase TN, Eastman JL, Niles JO, Niyogi D, Running S. 2002. The influence of land-use change and landscape dynamics on the climate system- relevance to climate change policy beyond the radiative effect of greenhouse gases. Philosophical Transactions of the Royal Society of London, Series A 360 $1705-1719$

Pitman AJ, de Noblet-Ducoudré N, Cruz FT, Davin EL, Bonan GB, Brovkin V, Claussen M, Delire C, Ganzeveld L, Gayler V, van den Hurk BJJM, Lawrence PJ, van der Molen MK, Müller C, Reick CH, Seneviratne SI, Strengers BJ, Voldoire A. 2009. Uncertainties in climate responses to past land cover change: first results from the LUCID intercomparison study. Geophysical Research Letters, DOI:10.1029/2009GL039076.

Pitman AJ, Narisma GT. 2005. The role of land surface processes in regional climate change: a case study of future land cover change over south western Australia. Meteorology and Atmospheric Physics 89: $235-249$.

Pitman AJ, Narisma GT, Pielke Sr RA, Holbrook NJ. 2004. The impact of land cover change on the climate of southwest Western Australia. Journal of Geophysical Research 109: D18109, DOI:10.1029/2003JD004347.

Podestá GP, Messina CD, Grondona MO, Magrin GO. 1999. Associations between grain crop yields in central-eastern Argentina and El Nino-Southern Oscillation. Journal of Applied Meteorology 38: $1488-1498$.

Ramankutty N, Foley JA. 1998. Characterizing patterns of global land use: an analysis of global croplands data. Global Biogeochemical Cycles 12: 667-685.

Ravelo A, Zanvettor R. 2000. Using the SPI to monitor the 1999-2000 drought in northeastern Argentina. Drought Network News 12: 3-4.

Reynolds RW, Smith TM. 1994. Improved global sea surface temperature analyses using optimum interpolation. Journal of Climate 7: 929-948.

Ropelewski CF, Halpert HS. 1987. Global and regional scale precipitation patterns associated with the El Niño/Southern Oscillation. Monthly Weather Review 115: 1606-1626.

Rusticucci M, Barrucand M. 2004. Observed trends and changes in temperature extremes over Argentina. Journal of Climate 17: 4099-4107.

SAGYPA. 2000. Estimaciones Agrícolas. Buenos Aires, Argentina: Secretaría de Agricultura, Ganadería, Pesca y Alimentación.

Satorre EH. 2005. Cambios tecnológicos en la agricultura actual. Ciencia Hoy 15: 24-31.

Sellers PJ, Los SO, Tucker CJ, Justice CO, Dazlich DA, Collatz GJ, Randall DA. 1996. A revised land surface parameterization (SiB2) for atmospheric GCMs. Part II: the generation of global fields of terrestrial biophysical parameters from satellite data. Journal of Climate 9: 706-737.

Siebert S, Döll P, Feick S, Frenken K, Hoogeveen J. 2007. Global map of irrigation areas version 4.0.1. University of Frankfurt (Main), Germany, and FAO, Rome, Italy.

SOTER. 1998. Soil and terrain database for Latin America and the Caribbean. FAO, CD-ROM. FAO Land and water digital media series. No. 5.

Strack JE, Pielke Sr RA, Steyaert LT, Knox RG. 2008. Sensitivity of June near-surface temperatures and precipitation in the eastern United States to historical land cover changes since European settlement. Water Resources Research 44: W11401, DOI:10.1029/2007WR00654.

Still CJ, Berry JA, Collatz GJ, DeFries RS. 2003. Global distribution of $\mathrm{C}_{3}$ and $\mathrm{C}_{4}$ vegetation: carbon cycle implications. Global Biogeochemical Cycles 17: 1006, DOI:10.1029/2001 GB001807.

Tsvetsinskaya E, Mearns LO, Easterling WE. 2001a. Investigating the effect of seasonal plant growth and development in 3-Dimensional atmospheric simulations. Part I: Simulation of surface fluxes over the growing season. Journal of Climate 14: 692-709.

Tsvetsinskaya E, Mearns LO, Easterling WE. 2001b. Investigating the effect of seasonal plant growth and development in 3-Dimensional atmospheric simulations. Part II: Atmospheric Response to Crop Growth and Development. Journal of Climate 14: 711-729.

Tucker CJ, Pinzon JE, Brown ME, Slayback D, Pak EWW, Mahoney R, Vermote E, El Saleous N. 2005. An extended AVHRR 8-km NDVI data set compatible with MODIS and SPOT vegetation NDVI Data. International Journal of Remote Sensing 26: 4485-4498.

UNFCCC. 2008. Clean Development Mechanism 2008 in brief. United Nations Framework Convention on Climate Change. p. 12.

USDA 1987. Major World Crop Areas and Climatic Profiles. USDA Agricultural Handbook No. 664.

Vega E, Baldi G, Jobbágy EG, Paruelo JM. 2009. Land use change patterns in the Río de la Plata grasslands: The influence of phytogeographic and political boundaries. Agriculture, Ecosystems and Environment 134: 287-292, DOI:10.1016/j.agee.2009.07.011.

Viglizzo EF, Frank FC, Bernardos J, Buschiazzo DE, Cabo S. 2006. A rapid method for assessing the environmental performance of commercial farms in the Pampas of Argentina. Environmental Monitoring and Assessment 117: 109-134.

Viglizzo EF, Roberto Z, Lertora F, Lopez G, Bernardos J. 1997. Climate and land use change in field-crop ecosystems of Argentina. Agriculture, Ecosystems and Environment 66: 61-70. 
Wagner W, Lemoine G, Rott H. 1999. A method for estimating soil moisture from ERS Scatterometer and soil data. Remote Sensing and Environment 70: 191-207.

Wagner W, Scipal K, Pathe C, Gerten D, Lucht W, Rudolf B. 2003. Evaluation of the agreement between the first global remotely sensed soil moisture data with model and precipitation data. Journal of Geophysical Research 108: DOI:10.1029/2003JD003663.

Walko RL, Band LE, Baron J, Kittel TGF, Lammers R, Lee TJ, Ojima DS, Pielke RA, Taylor C, Tague C, Tremback CJ, Vidale PL. 2000. Coupled atmosphere-biophysics-hydrology models for environmental modeling. Journal of Applied Meteorology 39: 931-944.

Wang H, Pitman AJ, Zhao M, Leemans R. 2003. The impact of landcover modification on the June meteorology of China since 1700, simulated using a regional climate model. International Journal of Climatology 23: 511-527, DOI:10.1002/joc.889.
Weaver CP, Baidya Roy S, Avissar R. 2002. Sensitivity of simulated mesoscale atmospheric circulations resulting from landscape heterogeneity to aspects of model configuration. Journal of Geophysical Research 107: 8041, DOI:10.1029/2001JD000376.

White MA, Thornton PE, Running SW. 1997. A continental phenology model for monitoring vegetation response to interannual climatic variability. Global Biogeochemical Cycles 11: 217-234.

World Bank. 2000. Policy Elements for Sustainable Development in the XXI Century. Argentina Water Resources Management. Latin America and the Caribbean Regional Argentina Country Department and Finance, Private Sector and Infrastructure, and Environment and Socially Sustainable Development.

Zwiers FW, von Storch H. 1995. Taking serial correlation into account in tests of the mean. Journal of Climate 8: 336-351. 